\title{
EL PRINCIPIO DE PUBLICIDAD EN LA TEORÍA KANTIANA DE LA ACCIÓN
}

\author{
Dulce María Granja*
}

RESUMEN: La necesidad de un orden jurídico global no se agota en las fronteras de un Estado-nación particular: la exclusión del Derecho es exclusión de lo humano. Resalta una concepción del Derecho abierta e incluyente, la cual corresponde a una concepción del ser humano como un ser que posee el derecho a tener derechos. Este reconocimiento sólo es posible en el horizonte de un uso público de la razón, favorecedor y promotor de una democracia deliberativa.

was

ABSTRACT: The need for a global legal order does not end at the borders of a particular StateNation: excluding law ignores everything that is human. The need for the creation of open and inclusive rights, in which human beings are perceived as being entitled to their rights, stands out. Acknowledging this fact is only possible in the context of public reason which favors and promotes a deliberative democracy.

PALABRAS CLAVE: Kant, cosmopolitismo, uso público de la razón, Derecho internacional, democracia deliberativa.

KEYWORDS: Kant, cosmopolitanism, public reason, international law, deliberative democracy.

RECEPCIÓN: 17 de abril de 2008.

ACEPTACIÓN: 22 de mayo de 2008.

* Centro de Documentación Kantiana, UAM-I. 
CITAM Derechos Reservados.

La reproducción total o parcial de este artículo se podrá hacer si el ITAM otorga la autorización previamente por escrito. 


\section{EL PRINCIPIO DE PUBLICIDAD EN LA TEORÍA KANTIANA DE LA ACCIÓN*}

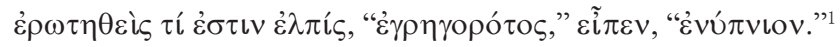

\section{Introducción}

$\mathrm{E}_{\mathrm{n} \text { su famosa obra Vidas y opinio- }}$ nes de los filósofos antiguos (circa 225 d. C.), Diógenes Laercio consigna que cuando alguien le preguntaba al antiguo filósofo griego Diógenes el cínico (404-323 a. C.), contemporáneo de Aristóteles, de dónde venía, cual era su origen, él contestaba: "soy cosmopolita... soy un ciudadano del mundo". ${ }^{2}$ Con esto quería decir que no deseaba definirse por su origen local o por su calidad de miembro de un grupo convencional, sino que más bien pretendía trasponer las fronteras de la patria y de la cultura y definirse en razón de sus aspiraciones y preocu-

* Este trabajo constituye la segunda parte de otro anterior, titulado asimismo "El principio de publicidad en la teoría kantiana de la acción, parte I", capítulo del libro Cosmopolitismo: democracia en la era de la globalización, 2009, Barcelona, Anthropos, p. 59-102. Ambos trabajos se complementan, pero pueden leerse separadamente.

${ }^{1}$ Véase Diógenes Laercio, Las vidas y opiniones de los filósofos antiguos, extraído del libro 5 que inicia con la "Vida de Aristóteles" fragmentos 5.18.2-3 en los que Diógenes afirma que preguntaron a Aristóteles qué es la esperanza, "el sueño -contestó- de un hombre despierto".

${ }^{2}$ Diógenes Laercio es un filósofo del que se sabe muy poco. Incluso son inciertas las fechas de su nacimiento y muerte. Lo conocemos por la única obra de él que ha llegado hasta nosotros: Vidas y opiniones de los filósofos antiguos, fechada entre 225 y $250 \mathrm{~d}$. C. Para el fragmento al que ahora hacemos referencia, véase el inicio de la "Vida de Diógenes" en el libro 6. 
paciones universales. Poco más tarde, $\operatorname{los}_{\text {estoicos }}^{3}$ argumentaron que cada uno de nosotros habita en dos comunidades: la comunidad local de nuestro nacimiento y la comunidad del razonamiento y aspiraciones humanas, que es la verdadera comunidad humana. Para los estoicos, en esta verdadera comunidad es donde encontramos la fuente normativa de nuestras obligaciones morales y nuestros valores fundamentales, de ahí que debamos considerar a todo ser humano como conciudadano nuestro. Para los estoicos, ser un ciudadano del mundo no significaba tener que renunciar a los gustos e inclinaciones de nuestra idiosincrasia local, que tan a menudo son una fuente de gran riqueza para la vida. Ilustraron su idea del cosmopolitismo sirviéndose de una imagen ${ }^{4}$ formada por numerosos círculos concéntricos: el primero es el de la identidad como individuo; le sigue el círculo del núcleo familiar; después viene el de la familia ampliada; enseguida el círculo de los vecinos y nuestro grupo local; más allá está el de los conciudadanos o compatriotas; y más allá de todos ellos y abarcándolos está el mayor de los círculos: el de la humanidad como un todo. Por ello los estoicos consideraron muy importante, para el adecuado conocimiento de uno mismo, reflexionar sobre la humanidad tal como existe en el mundo entero y ser capaz de descubrir y responder al rostro humano bajo todas sus formas y dondequiera que se dé. Sus textos muestran una y otra vez el daño que producen los bandos y las sectas con sus lealtades y componendas en la vida política de un grupo y cuán fácil

${ }^{3}$ La escuela estoica tuvo una vida extraordinariamente larga (de poco más de 500 años) y una gran influencia en el derecho y la literatura. Inició hacia fines del siglo IV a. C. con su fundador Zenón de Chipre y se extendió hasta el siglo II d. C. tanto en Atenas como en Roma; fueron sus últimos representantes Séneca, Epicteto, Marco Aurelio y Hierocles con su famosa Tabula de Cebes.

${ }^{4}$ Esta imagen la encontramos detalladamente desarrollada en Hierocles de Alejandría (siglo II d. C., casi contemporáneo de Epicteto) y de manera más breve en Cicerón, pero proba-

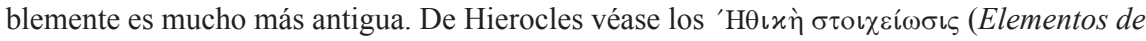
ética); para la descripción del cosmopolitismo bajo la figura de los círculos concéntricos, véase también Stobaeus, Florilegium, 4.671 y ss. De Cicerón véase especialmente De Officiis (Sobre los deberes). De Marco Aurelio sus Soliloquios o Meditaciones. Sobre este tópico en general véase A. A. Long, Stoic Studies, 1996, Cambridge University Press, cap. 11, así como el capítulo 2 titulado "Ciudadanos del Mundo" del libro de Martha Nussbaum El cultivo de la humanidad, 2005, Paidós, Barcelona. 
es que una comunidad sea manipulada por individuos interesados que sólo buscan su propio provecho y beneficio. Por eso invitan a que los hombres todos se reconozcan en una comunidad racional-moral y que la deliberación política se abra al escrutinio crítico de la razón del público en general. Posteriormente esta actitud influyó profundamente en Cicerón y en Marco Aurelio. Sin embargo, el pensador cosmopolita por antonomasia es Immanuel Kant, quien consideró el cosmopolitismo como un principio regulador del progreso de la sociedad humana hacia la integración universal y, por lo tanto, como el destino del género humano justificado por una tendencia natural en tal sentido.

En total contraste con las concepciones normativas de la política, las tesis del realismo político ${ }^{5}$ desde Tucídides, pasando luego por Hobbes y Maquiavelo, hasta E. H. Carr ${ }^{6}$ y Morgenthau, ${ }^{7}$ han afirmado que los individuos actúan motivados por intereses personales o de grupo y que para lograr sus objetivos se valen de incontables estrategias, muchas de las cuales están muy lejos de lo que podríamos considerar moralmente correcto. Y esto mismo puede decirse de los países y de los Estados. Para el realista político la guerra es algo a lo cual no se puede renunciar porque los Estados quedarían a merced de los intereses de otros más poderosos, además de que hay objetivos que no pueden ser logrados de otra manera que recurriendo a la guerra; así, ésta ha sido el recurso más antiguo y eficaz. El núcleo teórico del así llamado 'realismo político' sostiene la separación de dos ámbitos que, se dice, resultan incompatibles: la ética y la política. Este modelo maquiaveliano rompe con la tradición que venía desde la Grecia clásica, en la que con tanta hondura se pensó sobre la actividad política y a la que

${ }^{5}$ Cfr., Steve Forde, “Classical Realism”, en Nardin Terry \& Mapel David, Traditions of International Ethics, 1992, Cambridge Studies in Internacional Relations; véase también Martin Wigth, Internacional Relations Theory: Three Traditions, 1991, Holmes \& Meier Publishers.

${ }^{6}$ Edward Hallet, Carr, The Twenty Years 'Crisis, 1919-1936: An Introduction to the Study of Internacional Relations, 1946, Nueva York, Harper and Row.

${ }^{7}$ Cfr., Hans J. Morgenthau, Scientific Man Vs. Power Politics, 1946, University of Chicago Press. 
tanta dignidad se le confirió ${ }^{8}$ pues se estimaba que la vida política no puede desligarse de la vida moral. Igualmente lo rompe el realismo de corte hobbesiano en el cual los Estados, en tanto entes políticos autónomos, poseen naturalmente el derecho de defender sus intereses por encima de cualquier otro interés; de ello resulta que el mundo de las relaciones internacionales es de suyo anárquico y carente de leyes, pues los Estados no pueden depositar en una instancia superior la regulación de sus relaciones y no hay consideración moral que valga cuando se trata de defender los intereses de los Estados soberanos; el aspecto moral no tiene cabida cuando se trata del derecho soberano de los Estados de preservar sus intereses; por eso reina entre ellos un estado de naturaleza en el que la libertad que ejercen los Estados sólo está limitada por la fuerza con el que cada uno es capaz de imponerse. Así pues, la función principal de los políticos es la de velar y defender sus intereses contra las amenazas de todo tipo y la Raison d'État es el código que rige las relaciones internacionales, cuyo criterio dominante es el cálculo de costo-beneficio, la utilidad, la ganancia y la eficacia.

Sin embargo, después de las desoladoras experiencias de las dos devastadoras guerras mundiales, de los numerosos conflictos bélicos en el mundo árabe y el medio oriente y del sinnúmero de atentados terroristas y guerrillas que flagelan a millones de hombres en todo el planeta, se torna más y más urgente la necesidad de vivir en paz y la pregunta que se plantea inevitablemente es: ¿cómo pueden vivir juntos en comunidad hombres de diferentes culturas y religiones? Tal pregunta plantea retos y desafíos inéditos al Derecho internacional. Sin embargo, es una pregunta cuya respuesta la humanidad conoce en lo esencial desde hace mucho tiempo. En efecto, la globalización ${ }^{9}$ de las

${ }^{8}$ Cfr., Hannah Arendt, Entre el pasado y el futuro: ocho ejercicios sobre reflexión politica, 2003, Barcelona, Península; véase el cap. IV “¿Qué es la libertad?”, esp. p. 243-4.

${ }^{9}$ Siguiendo en esto a Jürgen Habermas entenderemos por 'globalización' un proceso en el que se extienden e intensifican las relaciones de comunicación, circulación e intercambio en los aspectos económicos, culturales y sociales por encima de las fronteras delineadas por los Estados-nación particulares. A causa del despliegue de los medios electrónicos de comunicación y de la expansión del mercado, este proceso incrementa la circulación de personas y el intercambio de información y de bienes tanto materiales como no materiales. Ello da por 
condiciones sociales ha repercutido enormemente en todos los ámbitos, pero quizá donde mayormente se ha puesto de relieve es en los del derecho, la economía, la política y la cultura, que afectan la organización de las sociedades humanas. Sin duda, la escena internacional contemporánea constituye un motivo de preocupación. Reflexionemos simplemente en problemas tales como el resurgimiento de formas más agresivas del nacionalismo a raíz del derrumbe del socialismo en la Unión Soviética y en Europa Oriental, la proliferación de los conflictos religiosos y étnicos, los fenómenos de migraciones masivas desde los países pobres hacia aquellos otros en los que está concentrada la riqueza, las enormes masas de población que sobreviven apenas debajo de la línea de pobreza, las guerras comerciales y el dramático contraste económico con los países industriales y postindustriales. Interculturalidad quizá sea el nuevo término que permitiría nombrar la situación específica de este momento histórico en que las migraciones masivas del sur hacia el norte irrumpen en comunidades políticas cuyo nivel de vida es muy superior al resto del planeta. Hoy más que nunca se ve la necesidad de llegar a una legislación que garantice y promueva los derechos de todos los seres humanos a integrarse en los procesos productivos, políticos, culturales y educativos globales. Y también hoy más que nunca nos preguntamos cómo lograrlo, cómo llegar al todo de una constitución civil justa que cobije y proteja los derechos universales de todo hombre. Nos preguntamos cuál ha de ser la naturaleza del régimen político que propicie y promueva tales derechos, qué papel juega la democracia en la era de la globalización, cómo ha de ser entendida esta forma de gobierno, qué rasgos de ella han de potenciarse para lograr la meta de equidad, desarrollo, integración y respeto que nos merece todo pueblo y todo hombre. Nos preguntamos

resultado la creación de numerosas y tupidas redes de relaciones entre los seres humanos a escala planetaria. Pero los problemas y riesgos se plantean también en esta misma escala global: desastres ecológicos que trascienden las fronteras de los Estados-nación particulares, grandes movimientos migratorios que traspasan fronteras, problemas económicos trasnacionales de efecto "dominó", etc. Véase Habermas, Die postnationale Konstellation und die Zukunft der Demokratie", en Jürgen Habermas, Die postnationale Konstellation. Politische Essays, 1998, Suhrkamp, Frankfurt am Main, p. 91-169, esp. p. 101. 
cuál es el papel que debe jugar en todo esto el proceso educativo, en el cual tomamos parte e influimos.

En esta era de globalización hay un tema especialmente actual: la necesidad de una teoría de la ordenación global del derecho y la paz. Para sorpresa nuestra este tema está plenamente presente en el pensamiento de Kant, a diferencia de muchos teóricos del derecho y del Estado, desde Hobbes hasta Hegel, que no imaginaron ni previeron la necesidad de tal ordenación. Kant establece los principios esenciales de ese ordenamiento y, con un énfasis extraordinario, subraya que "la razón, desde las alturas del máximo poder legislador, se pronuncia contra la guerra en modo absoluto, se niega a reconocer la guerra como un proceso jurídico, e impone, en cambio, como deber estricto, la paz entre los hombres". ${ }^{10}$

En el horizonte de la reflexión sobre estos problemas ha surgido en el campo de la filosofía política y la filosofía del derecho una corriente denominada 'cosmopolitismo', ${ }^{11}$ que si bien hunde sus raíces, como hemos dicho, hasta la más clásica tradición griega y romana, toma de la filosofía kantiana el análisis argumentativo que sirve de base y fundamento a un importante conjunto de nociones. De este modo, el cosmopolitismo presenta hoy novedosos rasgos que lo identifican como promotor de una reflexión sistemática sobre la justicia entendida no a nivel estatal-nacional sino más bien en un plano global; el cosmopolitismo busca lograr una reforma radical de las instituciones internacionales que permitan fomentar la cooperación internacional justa, la redistribución de la riqueza, la defensa de los derechos humanos universales y la preservación de la paz a escala internacional;

${ }^{10}$ Cfr., Hacia la paz perpetua, Segundo Artículo Definitivo, Ak. Ausg., VIII, 356. Todas las referencias que se harán a las obras de Kant en este trabajo serán hechas tomando en cuenta la edición de la Real Academia Prusiana de Ciencias, cuya abreviatura es Ak. Ausg; el número romano indica el tomo y los números arábigos las páginas de dicha edición.

${ }^{11}$ Véase Gillian Brock and HarryBrighouse, ed., The Political Philosophy of Cosmopolitanism, 2005, Cambridge, Cambridge University Press; véase también Sharon Anderson-Gold, "Kantische Grundlagen des gegenwärtigen Kosmopolitismus", en Deutsche Zeitschrift für Philosophie. Zweimonatsschrift der internationalen philosophischen Forschung, 2005, 53, Jahrgang, Heft 1, p. 97-109. 
igualmente, el cosmopolitismo trata de frenar y criticar las políticas que miran sólo por los intereses nacionales. Al subrayar la universalidad irrestricta de los deberes de la justicia, ${ }^{12}$ el cosmopolitismo entra en franca oposición con las distintas formas de comunitarismo para las cuales la prioridad se otorga a los miembros de unidades locales y sus derechos. ${ }^{13}$ Para el cosmopolitismo la universalidad irrestricta de los derechos humanos debe verse reflejada en la posibilidad de atribuir deberes que van más allá de las fronteras nacionales, poniendo a disposición de todo ser humano los bienes necesarios para su subsistencia y desarrollo de sus capacidades. Una tesis central del cosmopolitismo es aquella según la cual los derechos humanos plantean una pretensión moral de universalidad irrestricta. De ello resulta que los derechos humanos no pueden quedar acotados o reducidos a un orden jurídicolegal nacional particular, sino que más bien están vinculados y referidos a instituciones sociales cuya acción ha de ser global.

En diálogo con el gran pensador prusiano, este trabajo procurará destacar uno de los elementos más importantes de esa ordenación global del Derecho que Kant nos propone: el principio de publicidad. Igualmente, tratará de resaltar los vínculos de dicho principio con la democracia en esta era de la globalización. Quizá el rasgo esencial

${ }^{12}$ Para Charles Jones, por ejemplo, hay un vínculo indisoluble entre cosmopolitismo y validez universal de los derechos humanos; véase Charles Jones, Global Justice: Defending Cosmopolitanism, 1999, Oxford University Press.

${ }^{13}$ Hay cierto paralelismo o semejanza en las relaciones de incompatibilidad que se pueden establecer entre cosmopolitismo y comunitarismo, por una parte, y entre universalismo y liberalismo, por la otra. Sin embargo, yo no me ocuparé aquí de las disputas entre individualistas y comunitaristas (e.g., la polémica mantenida entre John Rawls con cuatro de sus principales críticos: Alasdair MacIntyre, Michael Sandel, Charles Taylor y Michael Walzer) ni entre universalistas y multiculturalistas; para ello puede verse el texto de Roberto Gargarella, Las teorías de la justicia después de Rawls. Un breve manual de filosofía política, 1999, Barcelona, Paidós, esp. p. 143 s. Por otra parte, es posible distinguir un comunitarismo 'conservador' representado por figuras tales como MacIntyre, Sandel y Bellah y un comunitarismo 'progresista' en el que se podría contar a Taylor, Unger o Walzer y Will Kymlicka; tampoco me ocuparé aquí de dichas distinciones; para ello pueden verse los trabajos de Carlos Thiebaut, Los límites de la comunidad: las críticas comunitaristas y neoaristotélicas al programa moderno, 1992, Madrid, Centro de Estudios Constitucionales, y de Fernando Llano Alonso, "Tres niveles axiológicos reconciliables dentro del proyecto humanista cosmopolita de Immanuel Kant”, en Anales de la Cátedra Francisco Suárez, 2001, p. 213-38. 
de la democracia consiste en que es una forma de gobierno en la cual el poder tiene límites. En la democracia el poder está acotado no sólo por su división tripartita, sino sobretodo por el principio de publicidad, el ejercicio público de la razón que anima en dicha separación de poderes y que exige transparencia en quien ostenta y ejerce el poder en cada una de esas tres esferas. Además, la opinión pública es una institución de la democracia y, como veremos, está sustentada sobre el ejercicio público de la razón. La formulación más conocida del llamado principio de publicidad es doble y se encuentra, como es bien sabido, en el segundo anexo del famoso ensayo de 1795 Hacia la paz perpetua. La primera formulación de dicho principio es negativa y reza así: Todas las acciones que afectan el derecho de otros hombres son injustas si su máxima no es compatible con la publicidad. ${ }^{14} \mathrm{La}$ segunda formulación es afirmativa y la encontramos un poco más adelante en los siguientes términos: Todas las máximas que requieren de la publicidad para no fracasar en sus propósitos, concuerdan con el derecho y la política a la vez. ${ }^{15}$

Dividiré este trabajo en cinco secciones. En la primera presentaré un breve resumen de las ideas centrales del célebre ensayo kantiano de 1795 Hacia la paz perpetua. En la segunda sección haré un repaso igualmente breve de la conclusión a la que nos llevó nuestra búsqueda por los fundamentos teóricos del principio de publicidad, con el objetivo de señalar y tratar de enmendar la errónea suposición sostenida por algunos filósofos contemporáneos, según la cual Kant limitó el uso público de la razón a un reducido grupo social. La tercera sección se dedicará a delinear claramente algunas distinciones terminológicas indispensables para describir la correcta relación que Kant establece entre derecho y moral, me refiero a las distinciones entre voluntad y albedrío, motivo e intención y máxima y ley. En la cuarta sección abordaremos la relación entre derecho y moral; y, en la quinta, destacaremos los rasgos más vigentes del cosmopolitismo que Kant propone. Para terminar, una referencia al epígrafe que encabeza este trabajo.

${ }^{14}$ Ak. Ausg., VIII, 381.

${ }^{15}$ Ibid., 386. 
E1 29 de septiembre de 1795 aparece publicado en Königsberg, por el editor Nicolovius, una edición que constaba de dos mil ejemplares de un pequeño ensayo titulado Hacia la paz perpetua. Sin embargo esa concisa brevedad nos revelará, parafraseando a Hannah Arendt, ${ }^{16}$ el gran virtuosismo de su autor. A primera vista podría parecer que Kant escribió este ensayo llevado por una mera circunstancia histórica: la paz de Basilea acordada hacía pocos meses, el 5 de abril de ese mismo año 1795, entre Prusia y Francia, en la cual Prusia se retira de la guerra y cede temporalmente a Francia sus territorios a la izquierda del Rhin. Sin embargo, el tema de la paz había atraído a Kant desde hacía mucho tiempo. En efecto, Kant no sólo conocía a fondo el debate sobre la paz entre los juristas del Derecho internacional, Grotius, Pufendorf, Saint-Pierre y Rousseau, sino que además él mismo ya se había ocupado de muchas de las piezas clave de este debate en numerosas obras anteriores a 1795, como lo son la Crítica de la razón pura ${ }^{17}$ de 1781 , en la que se encuentra ya el concepto de República, así como en la Idea para una historia universal en sentido cosmopolita ${ }^{18}$ de 1784 , en la que se plantea la integración de una sociedad civil que administre universalmente el Derecho. En la Crítica de la facultad de Juzgar, la gran obra de 1790, en la que encontramos la tesis fundamental de que la finalidad última de la naturaleza como sistema teleológico es la de una totalidad cosmopolita como sistema de todos los Estados. ${ }^{19}$ Igualmente, en el año de 1793 encontramos dos obras de gran relevancia en las que aparece de nuevo esta misma idea de una paz perpetua fundada en una federación de Estados como república mundial: me

${ }^{16}$ Cfr., Hannah Arendt, "What is freedom?", en Between Past and Future, 1968, New York, Penguin Books; de esta obra existe traducción castellana bajo el título de Entre el pasado y el futuro: ocho ejercicios sobre reflexión política, 2003, Barcelona, Península; véase p. 241-42 de esa edición.

${ }^{17}$ Véase $K r V$, A316, B372.

${ }^{18}$ Véase Ak. Ausg., VIII, 22-9.

${ }^{19}$ Véase Ak. Ausg., 429 s., $§ 83$. 
refiero a la Religión dentro de los límites de la mera razón ${ }^{20}$ y al ensayo Acerca del refrán: quizá esto sea cierto en teoría pero no sirve en la práctica ${ }^{21}$ Finalmente, en obras posteriores a la que ahora nos ocupa, Kant regresa sobre esta idea de una paz garantizada por una comunidad jurídica internacional, en la Doctrina del derecho ${ }^{22}$ de 1797, y en El conflicto de las facultades ${ }^{23}$ de 1798 . Así pues, podemos decir que la paz es un motivo fundamental y constante, presente permanentemente a lo largo de toda la obra de Kant y no sólo en su filosofía política. La idea de la paz está lejos de ser un núcleo conceptual ocasional en la filosofía kantiana; por el contrario, estamos ante una pieza teórica de gran valor, ante una parte irrenunciable del pensamiento kantiano en toda su amplitud: desde la filosofía moral y la filosofía de la historia hasta la filosofía del derecho y del Estado, pasando por el aspecto teleológico de la filosofía de la naturaleza.

El escrito kantiano sobre la paz fue un éxito literario rotundo: al primer tiraje de dos mil ejemplares siguió en pocas semanas una reimpresión de mil quinientos ejemplares más y la segunda edición de la obra vio la luz al año siguiente. Todavía en vida del filósofo (recordemos que Kant muere 1804, nueve años después de la primera impresión del estudio sobre la paz perpetua) esta obra ya llevaba diez ediciones. Ni las reseñas ni las traducciones se hicieron esperar por parte de plumas altamente competentes tanto en Alemania como en los países vecinos. Pero sobre todo, el texto fue muy leído e intensamente discutido desde entonces hasta nuestros días. En realidad se trata, como veremos, de un escrito 'revolucionario' en más de un sentido y no es ninguna casualidad que el proyecto de Kant se haya convertido en el plan de paz más famoso. En efecto, Kant supo conjuntar la verdadera universalidad propia de su filosofía crítica con el logro político más avanzado de su época, a saber, la república (representada en ese momento por la naciente República francesa) y ello le permitió crear

${ }^{20}$ Véase la Primera parte, III, de la Religión dentro de los límites de la mera razón, Ak. Ausg., VI, 34.

${ }^{21}$ Véase la tercera sección de dicha obra, Ak. Ausg., VIII, 307-13.

${ }^{22}$ Véase Metafisica de las Costumbres, Ak. Aug. 343-55 § 53-62 y conclusión.

${ }^{23}$ Véase El Conflicto de las facultades, Ak. Ausg., VII, 85-91. 
el plan político más atrevido y sugerente del que disponemos hasta ahora. Hagamos un breve resumen del contenido y forma de este célebre ensayo que nos permita apreciar algunos de sus rasgos más perdurables y atractivos.

Lo primero que debemos destacar es el estilo de la obra. Un aspecto que no podemos pasar por alto al referirnos a un libro filosófico es el de su estilo. El estilo de la expresión filosófica forma parte de la estructura misma del pensamiento expresado y revela la postura del autor sobre las cuestiones planteadas además de los alcances y límites de su escritura. Todo esto es de gran importancia para comprender adecuadamente el contenido filosófico de un escrito. El estilo no puede ser considerado aparte del contenido y por ello alterar el estilo de un pensador no es cuestión de poca monta, sino de hondas consecuencias. Si el contenido del famoso ensayo que estamos revisando nos demuestra que Kant fue un gran pensador político, el estilo del mismo nos revela que fue, además, un notable escritor de lo político. En efecto, es bien sabido que abordó no pocos de los problemas más arduos de la historia de la filosofía en los campos especulativo y práctico; sin embargo, es menos sabido que el gran pensador de Königsberg también abordó problemas no menos difíciles de manera elegante y afortunada, con un estilo ágil y popular. Si las tres Críticas son un ejemplo eximio del estilo austero y académico propio de un magister, el ensayo sobre la paz nos revelará a un Kant de la sociedad que escribe amenamente, renunciando por completo a los términos especializados y que se dirige a un vasto público abordando los temas de interés general. Kant fue, por así decirlo, un filósofo ambidiestro que cultivó tanto el estilo descrito por Schopenhauer como ‘brillantemente seco', o al que irónicamente se refería Heine como un estilo 'gris y seco, como papel de estraza', como aquel otro estilo ligero y ameno, trazado con tinta de vivos colores. ${ }^{24}$ Precisamente este estilo le permite transmitir la gran carga sugestiva del texto y podría resumirse diciendo: la paz no es

${ }^{24}$ En efecto, entre otros libros escritos con este mismo estilo ligero y ameno podemos contar las Observaciones sobre el sentimiento de lo bello y lo sublime, los Sueños de un vidente aclarados por la metafisica y la famosa Antropología en sentido pragmático. 
una ingenua utopía, no es una ficción irrealizable; la paz es posible, la paz es alcanzable.

Kant trata de emular lo más fielmente posible la estructura de los tratados de paz de aquel entonces y nos presenta una obra consistente en seis artículos preliminares, tres artículos definitivos que incluyen dos añadidos y un apéndice (en dos partes) y, con un fino sentido del humor, añade un artículo 'secreto'.

Lo primero que debemos decir es que, en total oposición al popular refrán que tanto circuló en el imperio romano y que era atribuido a Publius Flavius Vegetius, ${ }^{25}$ militar romano del siglo IV a. C. quien afirmaba Si vis pacem, para bellum (Si quieres la paz, prepárate para la guerra), Kant no busca una paz provisional y momentánea, entendida como una simple tregua en medio de las hostilidades; busca una paz sin reserva alguna, una paz perpetua e irrestricta; verdadera, sin fronteras, global, universal tanto temporal como espacialmente, una paz que podríamos llamar 'ecuménica': que se extienda a todas las culturas y todos los países.

En segundo lugar, debemos destacar que Kant coloca la paz perpetua en el campo del Derecho. Podríamos decir que para él la paz es un concepto netamente jurídico, pues sólo puede ser alcanzada por una labor del Derecho realizada por medio de las instituciones políticas. En efecto, veremos que Kant entiende la filosofía política como una filosofía del derecho y del Estado fundada sobre los principios morales de la coexistencia humana. No hay que esperar que la paz nos sea dada desde afuera, por la Providencia, por ejemplo. Tampoco hay que diferirla al lejano escatón del fin de los tiempos. ¡No! Los hombres mismos establecen la paz aquí y ahora pues el establecimiento de la paz es una obligación jurídico-moral. ${ }^{26}$

${ }^{25}$ Cfr., Publius Flavius Vegetius Renatus, Epitoma rei militaris también conocida como De Rei Militari.

${ }^{26}$ Kant se niega a reconocer la guerra como proceso jurídico y sólo cabe hablar de guerra de defensa ante una agresión no provocada. Que el establecimiento de la paz tenga el rango de un mandato incondicional, de una obligación jurídica y moral irrestricta, a punto tal que decir que el imperativo categórico del derecho es el imperativo categórico de la paz es algo que se puede apoyar en numerosos pasajes de esta obra entre los cuales podemos destacar: 356, línea 4; 362, línea 9; 364, línea 9 y 378 líneas 19-22 de la edición de la Academia. 
Los seis artículos preliminares cubren un amplio espectro temático. Sus destinatarios son los actores políticos (los soberanos, los parlamentos, etc.) y en ellos Kant se refiere a las violaciones del Derecho que deben ser suprimidas con el fin de establecer la paz en parte inmediatamente ('estrictas leyes prohibitivas') y en parte mediatamente o lo más pronto posible ('leyes permisivas').

Los tres artículos definitivos tienen como destinatarios los legisladores constitucionalistas y gobiernos así como los pueblos que los facultan. Estos tres artículos conforman el núcleo de la teoría kantiana de la paz y en ellos el filósofo explicita las condiciones morales y jurídicas de posibilidad que la paz supone y nos ofrece los elementos fundamentales de una teoría completa del Derecho público, examinando las tres únicas relaciones concebibles de lo político, a saber, el Derecho constitucional, el Derecho internacional y el Derecho cosmopolita. El desarrollo es el siguiente:

(1) En el Primer Artículo Definitivo se trata del Derecho constitucional, es decir, de las relaciones entre los individuos en el seno de una comunidad de derecho, a saber, en un Estado particular.

(2) En el Segundo Artículo Definitivo se trata del Derecho internacional, es decir, de las relaciones de los Estados particulares en una comunidad inter o supra nacional.

(3) En el Tercer Artículo Definitivo se trata del Derecho cosmopolita, es decir, de las relaciones entre individuos y grupos con Estados extranjeros.

En el llamado Artículo Secreto Kant demanda abandonar toda actitud secreta y abrir el lugar para una discusión libre y pública de todos los asuntos políticos por parte de los ciudadanos, en especial en los asuntos que atañen a la guerra y la paz. Veremos que esta franca oposición kantiana a la diplomacia secreta prevaleciente en su época, a la cual opone el principio de lo público o principio de publicidad, será enfatizando todavía más en la sección de los dos Apéndices del ensayo que nos ocupa. 
Por lo que toca a los dos Agregados que presenta el estudio sobre la paz, diremos brevemente que en el primero Kant ofrece una ampliación del concepto de paz, enlazándola con la teleología de la naturaleza y nos ofrece una propuesta de la historia de la humanidad determinada por la consecución de la paz como fin final. En el segundo agregado se ocupa de las relaciones entre la filosofía y el poder político. En lo referente a los dos anexos se examinan las relaciones y la compatibilidad entre política y moral. Para concluir esta primera sección, digamos solamente que a continuación nos ocuparnos detenida y cuidadosamente del principio de lo público y de las relaciones entre filosofía y poder político.

\section{2}

Al iniciar este trabajo nos hemos referido a la tarea ya realizada de haber dado cuenta y razón de que la actividad cognoscitiva subyace a la acción, de modo que era necesario revisar los presupuestos teóricos del principio de publicidad y las bases epistémicas del cosmopolitismo kantiano. Para Kant, el uso público de la razón es de enorme trascendencia pues la posición teórica está estrechamente vinculada con la posición política y tiene grandes repercusiones en la acción, a tal grado que podremos decir que tal uso público de la propia razón y la exigencia de libertad de pensamiento que éste conlleva se extenderá, como corolario, a la libertad de acción en toda su amplitud: libertad de opinión, libertad de comunicación, libertad de prensa, libertad civil, libertad política. En efecto, para Kant no existe ruptura alguna entre su teoría crítica y las repercusiones en la acción o proyecciones prácticas que ésta conlleva, pues para él la razón es en sí misma un sistema; ${ }^{27}$ por ello señalamos que se habría de dedicar una segunda parte de este trabajo para ocuparnos de dichas repercusiones en la acción. Quizá

${ }^{27}$ Entre los muchos pasajes de las diversas obras en que Kant se ocupa de la razón entendida como un sistema, cabe destacar los siguientes de la Crítica de la razón pura: B XXIII, A 671, B 699; así como A 738, B 766. Véase también Gerd Buchdahl, Kant and the Dynamics of Reason: Essays on the Structure of Kant's Philosophy, 1992, Blackwell Publishers. 
sea conveniente iniciar subrayando las conclusiones a las que llevó nuestra búsqueda por los fundamentos teóricos del principio de publicidad, y que podríamos resumir de la siguiente manera: los elementos teóricos o cognoscitivos que sustentan este doble principio se encuentran presentes a todo lo largo de la producción kantiana, de modo que podemos decir que la formulación ofrecida en los 'Apéndices' de la paz perpetua no es susceptible de aislarse del resto del sistema kantiano. En efecto, resulta sorprendente el número de pasajes en los que Kant insiste una y otra vez sobre esta temática, a punto tal que podemos insistir en sostener que estamos frente a una pieza de gran valor en la filosofía del pensador prusiano.

En los copiosos pasajes en los que examina el uso público de la razón, hay una tesis que se repite tenazmente una y otra vez y que va recibiendo, en la medida en que se desenvuelve, cada vez más detalle, riqueza y precisión. Dada la importancia de dichos pasajes, trataré de plegarme lo más posible al texto mismo del filósofo. Ya desde 1781 Kant subraya el reconocimiento de la necesidad de una discusión pública y libre, señalando en el prólogo de la primera edición de la Crítica de la razón pura que:

Nuestra época es, de modo especial, la de la crítica. Todo ha de someterse a ella. Pero la religión y la legislación pretenden de ordinario escapar de ella. La primera a causa de su santidad y la segunda a causa de su majestad. Sin embargo, al hacerlo, despiertan contra de sí mismas sospechas muy justificadas y no pueden exigir un respeto sincero, respeto que la razón sólo concede a lo que es capaz de resistir un examen público y libre. ${ }^{28}$

Más adelante, al iniciar la sección titulada disciplina de la razón pura en su uso polémico, ${ }^{29}$ volvemos a encontrar esta misma idea de la necesidad de la crítica, pero desarrollada ahora de manera más amplia y detallada. Así, leemos:

${ }^{28}$ Crítica de la razón pura, Ak. Ausg., III, A XI, nota.

${ }^{29}$ Ibid., A738-B766 hasta A757-B785. 
La razón pura tiene que someterse a la crítica en todas sus empresas. No puede oponerse a la libertad de esa crítica sin perjudicarse y sin despertar una sospecha que le es desfavorable. Nada hay tan importante, desde el punto de vista de su utilidad, nada tan sagrado, que pueda eximirse de esta investigación comprobadora y de inspección, investigación que no reconoce prestigios personales. Sobre tal libertad se basa la existencia misma de la razón, la cual carece de autoridad dictatorial. Su dictado nunca es sino el consenso de ciudadanos libres, cada uno de los cuales tiene que poder expresar sin temor sus objeciones e incluso su veto ${ }^{30}[\ldots]$ La razón pura representa el tribunal supremo de todos los conflictos. ${ }^{31}$ [...] Conviene, sin ninguna duda, dar plena libertad a la razón, tanto a la investigadora como a la examinadora, con el fin de que pueda procurarse su propio interés sin traba ninguna. ${ }^{32}$

Notemos dos importantes tesis que se engarzan en estos pasajes: en primer lugar, la tesis según la cual la existencia misma de la razón radica en este abierto ejercicio de la crítica y, en segundo lugar, que este examen público no reconoce prestigios personales, i.e., no se rige por el argumento de autoridad sino que ha de ser libre, irrestricto e imparcial. En efecto, Kant nos hará ver una y otra vez que la raíz de toda libertad es la libertad de pensar, que ésta última se asienta en la exigencia de pensar por sí mismo y que no pensaríamos mucho ni bien si no pensáramos en común con los demás.

Por otra parte, Kant sostiene que podemos considerar la crítica de la razón pura como el verdadero tribunal de todos sus conflictos; sin esta crítica, la razón se halla como en estado de naturaleza, sin poder hacer valer o asegurar sus tesis y sus pretensiones de otra forma que mediante la guerra. La crítica, en cambio, que deriva todas sus decisiones de las reglas básicas de su propia constitución y nos proporciona la seguridad de un Estado de derecho en el que no debemos llevar adelante nuestro conflicto más que a través de un proceso. En el primer estado, lo que pone fin a la disputa es una victoria de la que ambas partes se jactan

${ }^{30}$ Ibid., A 739 B 767.

${ }^{31}$ Ibid., A 740 B 768.

${ }^{32}$ Ibid., A 744 B 772. 
y a la que las más de las veces sigue una paz insegura, implantada por una autoridad que se interpone; en el segundo, es la sentencia. Ésta garantizará una paz duradera por afectar el origen mismo de las disputas. Como dice Hobbes, el estado de naturaleza es un estado de injusticia y de violencia, y es preciso abandonarlo para someterse al imperio de la ley, único que limita nuestra libertad de forma que pueda coexistir con la de todos los demás y, por ello mismo, con el bien común. También forma parte de esta libertad el exponer a pública consideración los propios pensamientos y las dudas que no es capaz de resolver uno mismo, sin por ello ser tachado de alborotador o de ciudadano peligroso. Esto entra ya en el derecho originario de la razón humana, la cual no reconoce más juez que la misma razón humana común, donde todos tienen voz. Como todo perfeccionamiento del que nuestro estado sea capaz tiene que derivar de esa voz, tal derecho es sagrado e irrestringible.

Me he permitido subrayar estas líneas a fin de destacar el tono enfático con que están escritas y que nos revela la importancia que para Kant tenía este núcleo temático al cual, como veremos, volverá insistentemente una y otra vez. Notemos pues, que se trata de un derecho universal e inalienable.

Lo primero que salta a la vista en este importante fragmento es la velada comparación que Kant establece entre derecho y filosofía. Esta comparación me parece enormemente significativa pues encierra la doble faceta, intelectual y política, del principio de publicidad y nos señala que en la base de esa legislación y formando parte de ella se encuentra la pública exposición de los propios pensamientos (e incluso de las propias dudas que uno no es capaz de resolver por sí mismo) y esto forma parte del derecho originario de la razón humana común de la que todos participan. Para Kant, la educación no otorga o concede el derecho de exponer a pública consideración los propios pensamientos, sólo desarrolla las habilidades y destrezas necesarias para el ejercicio de dicho derecho. Es éste un derecho originario de la razón humana común, donde todos tienen voz y como todo perfeccionamiento del que el hombre es capaz se deriva de esa voz universal, tal derecho es sagrado e irrestringible, i.e., se trata de un derecho que no 
se puede alienar, ceder ni cancelar. Así pues, Kant insiste nuevamente subrayando la tesis que ya antes había sostenido, ${ }^{33}$ según la cual la razón posee esa prerrogativa que la convierte en el mayor bien sobre la tierra: ser la última piedra de toque de la verdad.

Refirámonos ahora a un conjunto de ideas sumamente afines a las que hemos brevemente revisado y que vemos aparecer una y otra vez en las páginas de las Lecciones de lógica, la Crítica de la Facultad de Juzgar, la Antropología desde un punto de vista pragmático y algunas Reflexiones.

Estando a punto de concluir la Introducción a sus Lecciones de lógica ${ }^{34}$ Kant se refiere a un tema de crucial importancia para examinar lo que hoy podríamos llamar 'distorsiones cognoscitivas' o conocimientos falsos, y señala que existen tres reglas para evitar los errores en general. Así Kant nos propone: "Las reglas y condiciones para evitar los errores en general son: 1) pensar por sí mismo; 2) pensarse en la posición de otro; y, 3) pensar en todo momento de acuerdo consigo mismo. La máxima de pensar por sí mismo se puede llamar modo de pensar ilustrado; la máxima de trasladarse en el pensamiento a puntos de vista ajenos, modo de pensar ampliado y la máxima de pensar siempre de acuerdo consigo mismo, modo de pensar consecuente o franco." Kant vuelve a bordar cuidadosamente sobre este mismo tema en un pasaje de enorme riqueza de la Crítica de la facultad de juzgar:

A la facultad de juzgar se le da a menudo el nombre de 'sentido' y así se habla, por ejemplo de 'sentido de la justicia', 'sentido del decoro'. Por 'sentido común' (sensus comunis) hay que entender un sentido común a todos, es decir, una facultad de juzgar que en su reflexión tiene en cuenta el modo representacional de cada uno de los demás, para atener su juicio a la entera razón humana y huir así de la ilusión nacida de tener las condiciones meramente subjetivas y privadas por objetivas. Ahora bien, esto se logra al atener el propio juicio al juicio de otros y al ponerse en el lugar de los otros; lo cual, a su vez, se lleva a cabo

${ }^{33}$ Cfr., Crítica de la razón pura, A 740 B 768, línea 6, en la segunda edición: "la razón es el tribunal supremo de todos los conflictos".

${ }^{34}$ Cfr., Ak. Ausg., XXIV, 57. 
mediante la operación de la reflexión que consiste en hacer omisión o abstracción de todo aquello que es atractivo, emoción, materia y sensación prestando atención únicamente a las peculiaridades formales de la propia representación. Nada más común y natural que esta operación del común entendimiento humano. Estas son las máximas del común entendimiento humano: 1. Pensar por sí mismo; 2. Pensar en el lugar de cada otro; 3 . Pensar siempre de acuerdo consigo mismo. La primera es la máxima del modo de pensar libre de prejuicios; la segunda, del extensivo, la tercera, del consecuente. La primera es la máxima de una razón nunca pasiva.$^{35} \mathrm{La}$ inclinación a lo contrario, por tanto, a la heteronomía de la razón, se llama prejuicio, y el mayor de todos consiste en representar la naturaleza como no sometida a reglas que el entendimiento, por su propia ley esencial, le pone a la base, es decir, la superstición. La liberación de la superstición se llama Ilustración, porque aunque esa denominación se da también a la liberación de los prejuicios en general, la superstición merece preferentemente (in sensu eminente) ser llamada prejuicio, en cuanto que la ceguera en que ella nos sume, y que impone incluso como obligada, da a conocer la necesidad de ser conducido por otros, y, por tanto, el estado de una razón pasiva. En lo que toca a la segunda máxima del modo de pensar, estamos acostumbrados a llamar limitado (corto de alcances, estrecho, lo contrario de amplio) a aquel cuyos talentos no alcanzan para ningún uso grande (sobre todo, para el uso intensivo). Pero aquí no se trata de la facultad del conocimiento, sino del modo de pensar, para hacer de éste un uso conforme a fin; por muy pequeña que sean la envergadura y el grado a que alcance el don natural del hombre, indica, sin embargo, a un hombre de pensar amplio, cuando éste puede apartarse de las condiciones privadas y subjetivas del juicio, dentro de las cuales tantos otros están como atrapados, y reflexiona sobre su propio juicio desde un punto de vista universal (que sólo puede determinar poniéndose en el punto de vista de los demás). La tercera máxima, a saber la del modo de pensar consecuente, es la más difícil de alcanzar, y no puede alcanzarse más que por la unión de las dos primeras, y después de una frecuente aplicación de las mismas, convertida ya en destreza. Puede decirse: la primera de esas máximas

${ }^{35}$ Lo contrario sería una razón perezosa; al respecto puede consultarse además Religión dentro de los límites de la mera razón, Ak. Ausg.: VI, 57; 133 nota; 134 nota (que trata sobre la fe pasiva). Véase también $\mathrm{V}, 38$ que trata sobre la tranquilidad de una conciencia perezosa. 
es la máxima del entendimiento; la segunda, de la facultad de juzgar; la tercera, de la razón. ${ }^{36}$

Aún corriendo el riesgo de resultar pesadamente reiterativa, no puedo dejar de señalar que para Kant estamos frente a un derecho originario de la razón humana común donde todos tienen voz; así pues, se puede decir que la verdadera revolución copernicana está en el sensus comunis entendido como esta intersubjetividad y libertad comunicativa o comunicación libre de dominio, que Kant está defendiendo.

En la Antropología, vemos que Kant insiste en este mismo núcleo temático en varias ocasiones. Así, leemos:

Se supone que es demasiado pedirles a los hombres sabiduria, entendida como la idea del uso práctico de la razón, conforme a leyes y perfecto; pero ni siquiera en un grado mínimo puede infundirla un hombre en otro, sino que él tiene que sacarla de sí mismo. El precepto para llegar a ella encierra tres máximas conducentes a conseguirlo: 1. pensar por su cuenta, 2. ponerse (al comunicar con los hombres) en lugar del prójimo, 3. pensar en todo tiempo acorde consigo mismo. ${ }^{37}$

En otro precioso texto, Kant sigue insistiendo en el mismo motivo con las siguientes palabras:

Mediante la gran diversidad de las cabezas en la forma como consideran los mismos objetos y se consideran mutuamente, mediante el roce de unas con otras y su enlace tanto como su separación, produce la naturaleza una obra de teatro digna de verse, por su infinita variedad, en el escenario de los observadores y pensadores. Para la clase de los pensadores puede hacerse de las siguientes máximas (que ya fueron mencionadas anteriormente como conducentes a la sabiduría) mandamientos inmutables: 1. Pensar por su cuenta. 2. Imaginarse (al comunicar con los demás) en el lugar de cualquier otro. 3. Pensar en todo tiempo acorde consigo mismo. El primer principio es negativo (nullius addictus iurare

${ }^{36}$ Crítica de la facultad de juzgar, $\S 40$.

${ }^{37}$ Antropología, § 43, 200. 
in verba Magistri), ${ }^{38}$ el del modo de pensar libre de coerción; el segundo, positivo, el del modo de pensar liberal que se acomoda a los conceptos de los demás; el tercero, del consecuente; de cada uno de los cuales, pero todavía más de sus contrarios, puede poner ejemplos la Antropología. La más importante revolución en lo interior del hombre es: "la salida de éste de su incapacidad por culpa propia" ${ }^{39}$ En lugar de pensar otros por él y limitarse él a imitar o a dejarse llevar con andadores, como hasta ese momento, osa ahora avanzar, aunque todavía vacilantemente, con sus propios pies sobre el terreno de la experiencia. ${ }^{40}$

Para finalizar pondremos a consideración del lector tres Reflexiones en las que Kant no podía ser más taxativo al detallar aún más el sentido de estas tres máximas que hemos visto repetirse una y otra vez. La primera Reflexión dice así: "Dado que consideramos como necesario informar a los demás acerca de nuestros juicios, entonces no tenemos que ser únicamente comunicativos, sino además participativos. La propensión a la comunicación que guía nuestro entendimiento se encuentra en nosotros únicamente porque debemos verificar nuestros propios juicios mediante los juicios de otros." ${ }^{41}$

En la segunda Reflexión leemos:

La inclinación comunicativa de la razón es equitativa sólo bajo la condición de que esté enlazada a la vez con la participativa. Los otros no son aprendices, tampoco son jueces, sino colegas, en el gran consejo de la razón humana y tienen votum consultativum y unanimitas vototrum est pupilla libertatis. Liberum veto. ${ }^{42}$

Finalmente, en la tercera Reflexión Kant señala:

${ }^{38}$ Kant está citando a Horacio, Epistolas, I, 1, 14; esta expresión latina podría traducirse como ninguna sujeción me ha obligado a jurar por las palabras de un maestro.

${ }^{39}$ Kant repite aquí las palabras con las que inicia su célebre ensayo de 1784, Respuesta a la pregunta ¿Qué es la Ilustración?, Ak. Ausg., VIII, 35. Véase también el pasaje $\S 48$ de la Antropología en donde Kant habla de la "minoría" de edad. Ésta, "la más importante revolución”, es lo que he considerado el corazón de la Revolución copernicana.

${ }^{40}$ Antropología, § 59, 228.

${ }^{41}$ Reflexión 2565, Ak. Ausg., XVI, 419.

${ }^{42}$ Reflexión 2566, Ak. Ausg., XVI, 419-20. 
Puesto que la validez universal de nuestros juicios indica la verdad objetiva para cualquier razón, se sigue la necesidad de una razón participativa que se opone al egoísmo y que el juicio de otros sea un criterio externo de la verdad; por lo mismo el derecho de dar a conocer los propios juicios y la lealtad como el motivo impulsor de las ciencias. Un entendimiento y una voluntad participativa son buenos siempre; un entendimiento sano y correcto va siempre unido a la honradez y viceversa. El beneficio de la duda en el juicio provisional de los otros consiste en pensar que cuando los otros ostensiblemente parecen haber cometido un error, se prefiere creer que es uno quien no los ha entendido. Egoísmo ${ }^{43}$ es el prejuicio de la indiferencia respecto del juicio de otros considerado como criterio de verdad de nuestro juicio. Ponerse en el lugar de otros al pensar quiere decir probar en otros el juicio propio. ${ }^{44}$

Pasemos ahora a referirnos al escrito intitulado Respuesta a la pregunta ¿Qué es la Ilustración?, fechado en septiembre de 1784 y publicado en diciembre de ese mismo año. En la primera línea del escrito Kant ofrece su respuesta a dicha pregunta: Ilustración es la salida del hombre de su auto culpable minoría de edad. Minoría de edad es para Kant la incapacidad de valerse del propio entendimiento sin tutela alguna. Y esa incapacidad es culpable cuando su causa no es la falta de entendimiento sino la pereza y la cobardía para servirse de éste sin sujetarse a la dirección de otro. Tenemos que atrevernos a pensar por nosotros mismos; ésta es la máxima de la Ilustración: iSapere aude!. ${ }^{45}$ Notemos que Kant, haciendo una paráfrasis de la expresión de Horacio, la glosa como Ten el valor de servirte de tu propio entendimiento. Así pues, no es casual esta vinculación que hace Kant entre la sabiduría y las máximas del común entendimiento humano como reglas para evitar los errores.

${ }^{43}$ Véase también Antropología, VII, 129 y 130.

${ }^{44}$ Reflexión 2564, Ak. Ausg., XVI, 418-19. Véase además, Crítica de la razón pura, A 476, B 504.

${ }^{45}$ Sapere aude puede traducirse como iAtrévete a ser sabio! o iTen la audacia de ser sabio! Con esta expresión Kant está citando un fragmento de Horacio, uno de sus poetas latinos favoritos: Epodos, I, 2, 40. Véase Ak. Ausg., VIII, 35. 
Resumiendo, baste decir que por uso público de la propia razón Kant entiende aquel que alguien hace de ella en cuanto propiamente docto ante el gran público del mundo de los lectores. ${ }^{46}$ ¿Qué entiende Kant por Gelehrter o docto? Veremos que Kant se apartará de una definición austera de Gelehrter que comprende solamente haber hecho estudios. Así, El conflicto de las facultades ${ }^{47}$ inicia con la distinción entre los propiamente doctos y los meramente letrados; éstos han hecho estudios pero han retenido sólo lo que es imprescindible para el ejercicio de un cargo público; son negociantes del saber que utilizan este último en provecho propio y no precisamente en aras de las ciencias; esta clase especial de letrados, lejos de ser libre para hacer un uso público de sus conocimientos, se halla bajo la censura de sus facultades (universitarias) respectivas y se comporta pasivamente y sin argumentar acerca de la pertinencia o utilidad de tal o cual orden de sus superiores. ${ }^{48}$

En contraste, dicho correctamente, docto es quien usa verdaderamente su entendimiento para hablar en nombre propio al gran público de lectores, exponiendo mediante escritos sus pensamientos cuidadosamente examinados, sometiendo libre y públicamente al examen del mundo sus juicios y opiniones y haciendo propuestas para el mejoramiento o progreso del destino de la humanidad. ${ }^{49}$ En efecto, según hemos visto, el único sentido de ser intelectual es ser crítico y no pensaríamos mucho ni bien si no pensáramos en comunidad con los demás. Hemos de señalar que el vehículo idóneo de la crítica y el uso público de la razón es la manifestación escrita de nuestros pensamientos, pues ésta propicia la expresión puntual, rigurosa y firme de lo que se piensa o dice. En resumen: uso público de la razón es el que hace quien, poniendo en práctica las tres máximas señaladas, habla en nombre propio (en primera persona) y somete al examen del gran público del mundo de los lectores sus propios juicios.

${ }^{46}$ Respuesta a la pregunta ¿Qué es la Ilustración?, Ak. Ausg., VIII, 36-37.

${ }^{47}$ Cfr., Ak. Ausg., VII, 17-18

${ }^{48}$ Respuesta a la pregunta ¿Qué es la Ilustración?, Ak. Ausg., VIII, 37 y sig.

${ }^{49}$ Ibid., Ak. Ausg., VIII, 38. 
Lo primero que salta a la vista al leer este famoso ensayo de 1784 es el énfasis con el que Kant subraya la importancia del uso público de la razón y cómo la libertad de pensar repercute y redunda en la libertad de acción. En efecto, Kant no puede ser más taxativo al declarar que un contrato que excluyera toda ulterior Ilustración es, sin más, nulo y sin efecto, absolutamente ilícito, por más que fuera confirmado por el poder supremo. ${ }^{50}$ Una constitución que imposibilita que los hombres amplíen sus conocimientos o los depuren de errores y avancen en la Ilustración es un crimen contra la naturaleza humana y equivale a violar y pisotear los sagrados derechos de la humanidad. En efecto, ya hemos visto ${ }^{51}$ que, como todo perfeccionamiento y mejora de la que el ser humano es capaz deriva del derecho originario de la razón humana común, donde todos tienen voz, tal derecho es sagrado e irrestringible. De esto resulta que la autoridad del gobernante está limitada por el uso público de la razón, ${ }^{52}$ pues si a un pueblo no le estuviera permitido decidir por y para sí mismo, menos aún lo podrá hacer un monarca en nombre de aquél, pues su autoridad legisladora descansa, precisamente, en que reúne la voluntad de todo el pueblo en la suya propia. Kant volverá a insistir en esta misma idea en la Metafísica de las costumbres con los siguientes términos: "lo que no puede decidir el pueblo (la masa total de los súbditos) sobre sí mismo y sus componentes, tampoco puede el soberano decidirlo sobre el pueblo." ${ }^{53}$ Lo segundo que deberá destacarse en este ensayo es que ya desde esta temprana fecha Kant asienta la pretensión de validez o principio de legitimidad propio de la democracia en la libertad de pensamiento y el uso público de la razón. En efecto: toda autoridad legislativa descansa precisamente en que asume la voluntad entera del pueblo en la suya propia, puesto que la piedra de toque de todo lo que puede decidirse como ley para un pueblo se halla en esta interrogación: ¿un pueblo

${ }^{50}$ Ibid., Ak. Ausg., VIII, 39

${ }^{51}$ Véase Crítica de la razón pura, A 751 B 779 y sig.

${ }^{52}$ Kant emplea una expresión latina muy usual: Caesar non est supra grammaticos, que podría traducirse como Cesar no está por encima de los letrados.

${ }^{53}$ Véase Ak. Ausg., VI, 329. 
hubiera podido imponerse a sí mismo esta ley? ${ }^{54}$ Así pues, para Kant el poder legislativo tiene que pertenecer al pueblo y el principio de soberanía del pueblo sólo puede ser realizado bajo el presupuesto de un uso público de la razón que se basa, como pronto veremos, en la libertad como principio y fin. ${ }^{55}$

Kant terminará su famosa Respuesta con una idea en la que se recapitula lo dicho hasta ahora:

Una vez que la naturaleza [...] ha desarrollado la semilla que cuida con extrema delicadeza, es decir, la propensión y atracción a pensar libremente, este hecho va repercutiendo gradualmente sobre el sentir del pueblo $^{56}$ (con lo cual éste se va haciendo cada vez más capaz de actuar libremente) hasta llegar eventualmente a los principios del gobierno, el cual juzga ventajoso por sí mismo tratar al hombre, que ahora es más que una máquina, conforme a su dignidad. ${ }^{57}$

Aún corriendo el riesgo de que mi insistencia pueda llegar a ser pesada para el lector, quiero destacar que este uso público de la razón es el motor de la democracia y del proceso humanizador de las instituciones o, siguiendo en esto a Maus, de la institucionalización de las ideas morales. ${ }^{58}$ En efecto, la moralidad no puede quedar limitada al ámbito de lo individual porque esto no basta; es imprescindible que

${ }^{54}$ Kant vuelve a insistir en este criterio de legitimidad en el corolario de la segunda sección (contra Hobbes) de su escrito de 1793, Acerca del refrán "tal vez esto es cierto en teoría pero no sirve para la práctica”, Ak. Ausg., VIII, 297-306.

${ }^{55}$ Kant insistirá en esta idea según la cual la soberanía del pueblo se basa en la libertad como principio y como fin; véase más adelante el examen de la Metafisica de las costumbres $\S \S 45$ y 46, Ak. Ausg., VI, 313-314; véase también El conflicto de las facultades, Ak. Ausg., VII, 87 nota.

${ }^{56}$ Me he permitido subrayar la palabra 'pueblo' a fin de recordar al lector que estamos frente a un derecho universal y no sólo de algunos pocos grupos o individuos (e.g., los instruidos o los propietarios) como ha sido interpretado erróneamente por la Escuela de Frankfurt.

${ }^{57}$ Respuesta a la pregunta ¿Qué es la Ilustración?, Ak. Ausg., VIII, 40-41. Esta dignidad, como bien se encarga Kant de señalarlo, estriba en que el hombre es un fin en sí mismo, característica ésta que deriva de su naturaleza racional y libre.

${ }^{58}$ Cfr., I. Maus, Zur Aufklerung der Demokratietheorie, 1992, Frankfurt, Suhrkamp; también Goodin, R. E., (comp.), Teoría del diseño institucional, 2003, Barcelona, Gedisa. 
preñe a las instituciones. Moralizar las instituciones no es otra cosa que humanizar las instituciones, ${ }^{59}$ i.e., que éstas se sometan a y se rijan por un uso público de la razón. Esto nos llevará de la mano a lo que podríamos designar como una cuarta formulación del imperativo categórico. En otras palabras, es tal la magnitud y complejidad de los problemas sociales que no bastan las soluciones asiladas, individuales y particulares, sino que se requieren soluciones institucionales, públicas, a nivel de la sociedad en su conjunto, lo cual implica que dichas soluciones sean administradas por la ley o según la ley.

La exigencia de una discusión abierta, pública y libre en la que todos deben participar sin restricciones es lo totalmente opuesto al fanatismo, que podría describirse como un secuestro de la razón pues la comunicabilidad y la participación sin restricciones son la esencia misma de la razón. Como lo muestra palmariamente la Antropología, Kant fue un fino conocedor de la psicología y la cultura de los pueblos y nada le fue más ajeno que pretender defender un monopolio de la razón, es decir, una sola y única forma de racionalidad, igual en todos los hombres y en toda época. Para Kant, en el gran consejo de la razón humana, todos tienen voz y su filosofía se opone totalmente a dar preeminencia a una razón exclusiva y excluyente. Acaparar la razón y pretender que prevalezca una razón homogénea y única que se impone a los demás equivale a ir en contra de la máxima del pensar extensivo y sostener la errónea pretensión de privilegiar una penuria de la razón, esto es, una razón empobrecida, estéril y precaria, en la que no hay lugar para la diversidad, la riqueza y la pluralidad. Nada más contrario a la posición kantiana que sostener que sólo hay una cultura conforme a la razón y que la razón sólo puede dar lugar a una única forma de civilización, de modo tal que las demás culturas sólo tienen valor como estadios en evolución hacia esa cultura superior. Para Kant, en vez de subordinar la multiplicidad de culturas a una sola y única manifestación hegemónica de la razón, se debe comprender la razón como resultado de una pluralidad inagotable de culturas. La antípoda

${ }^{59}$ En efecto, podría decirse que la moralidad es simplemente la forma que toma la vida humana; en realidad, no hay forma de vida humana que no sea la forma moral de vida. 
del pensamiento kantiano es considerar el mundo como el escenario de lucha entre Estados soberanos; en vez de esto, el mundo ha de ser concebido como una unidad de convivencia de regiones, pueblos, culturas y etnias en la que ningún pueblo ha de quedar marginado o excluido, i.e., como una sociedad civil universal o cosmopolitisimus. ${ }^{60}$ En resumen: las máximas para evitar el error no son sino las máximas para alcanzar la sabiduría, y éstas no son otras que las máximas del común entendimiento humano, es decir, las máximas en las que se tiene en cuenta el modo de pensar de los demás. En especial, la máxima del pensar extensivo es el resorte de la capacidad de autocrítica. En otras palabras: el error no puede evitarse y la sabiduría no puede alcanzarse sin reflexionar sobre el propio juicio desde un punto de vista universal o cosmopolita, y esto sólo puede hacerse poniéndose en el punto de vista de los demás. Nada más contrario a la posición kantiana que sostener un pensamiento único y homogeneizador en el que el consenso corre menos peligro que el disenso. Como veremos, el principio de publicidad puede ser entonces un potente instrumento de diálogo, de emancipación y de diversidad.

Según se puede ver, es claro que, a pesar de lo que suele decirse siguiendo en eso a importantes filósofos contemporáneos, ${ }^{61}$ el pensamiento del sabio de Könisgberg está muy lejos de ser una filosofía de la conciencia, un idealismo solipsista en el que se define la razón mediante la pura y abstracta subjetividad y que necesite transitar hacia una filosofía de la intersubjetividad y de la comunicación. Sería más justo y objetivo decir que propuestas tales como la 'razón comunicativa' o la 'comunidad de comunicación' simplemente continúan y desarrollan el plan del propio Kant, el mismo plan que Kant dejara trazado, y no que tales propuestas subsanan las carencias que erróneamente dichos filósofos suponen ver en ese plan. También deseo insistir en que los textos que hemos citado nos permiten ver igualmente con

${ }^{60}$ Véase Antropología, Ak. Ausg., VII, 331.

${ }^{61}$ Me refiero a los filósofos de la Teoría Crítica de la Escuela de Frankfurt. Véase, e.g., K.O. Appel, Transformation der Philosophie, 1973 Suhrkamp, y J. Habermas, Moralität und Sittlichkeit, hrsg. V. W. Kuhlmann, 1986. 
toda claridad que, cuando Kant habla de libertad de pensamiento, la atribuye al pueblo y no sólo de algunos pocos grupos o individuos, los instruidos o los propietarios burgueses como se ha interpretado erróneamente, por ejemplo, por Habermas ${ }^{62}$ y algunos otros discípulos suyos. No hay duda de que Kant está hablando del público, del común de la gente, del pueblo en general y en este punto no puede ser más taxativo. En efecto, Kant ha afirmado páginas atrás, al inicio de esta famosa Respuesta, que "es casi inevitable que el público se ilustre a sí mismo cuando se le deja en libertad". ${ }^{63}$ Se hace necesario destacar dos textos más que permiten ver lo erróneo de la interpretación de la escuela de Frankfurt en este punto. Kant refiere el uso público de la razón al común de la gente $\mathrm{y}$, por eso precisamente, el filósofo no puede reclamar habilidades o privilegios especiales; el filósofo ejerce una competencia que es común a todos los hombres: "el criterio libre de la razón". ${ }^{64}$ Por ello el pensador profesional, el filósofo, no tiene "un conocimiento más elevado y amplio" que "la gran masa, para nosotros dignísima de respeto". ${ }^{65}$ Examinar detalladamente esta masa crítica $^{66}$ es algo que podremos hacer al ocuparnos más adelante del derecho a tener derechos como cualidad moral propia de todo ser humano.

Recapitulando, publicidad no significa solamente comunicación con el público, ${ }^{67}$ sino que posee una importante dimensión filosófica dilucidada por Kant. En la segunda parte de este trabajo veremos que

${ }^{62}$ Véase, Habermas, L'espace public, 1978, Paris, Payot, p. 116 y 119.

${ }^{63}$ Cfr., Respuesta a la pregunta ¿Qué es la Ilustración?, Ak. Ausg., VIII, 36.

${ }^{64}$ Cfr., Hacia la paz perpetua, Ak. Ausg., VIII, 369.

${ }^{65}$ Cfr., Crítica de la razón pura, B xxxiii.

${ }^{66}$ Sobre el concepto de "masa crítica" véase el muy interesante libro de Philip Ball Critical Mass, 2005, Arrow Books, Random House. Véase también la sección titulada "Si el género humano se halla en constante progreso hacia lo mejor" de la obra kantiana de 1798 El conflicto de las facultades.

${ }^{67}$ Es interesante recordar que el origen de este vocablo es la palabra latina publicus, la cual tomó su significado original de la voz populus y que podríamos traducir como el pueblo o los habitantes de un estado. Es justamente en ese sentido que Cicerón dice: Populus non omnis hominum cœtus multitudinis juris consenso et utilitatis communione sociatus, es decir: "un pueblo no es toda reunión de hombres reunidos al azar, sino únicamente una sociedad formada bajo la tutela de las leyes y con una finalidad de utilidad común". Así pues, podría decirse que pueblo es el estado en tanto que éste descansa sobre la comunidad de seres humanos. 
existe un común denominador en los copiosos escritos cuya revisión emprenderemos; por el momento, baste señalar que en todos ellos Kant avanza en el significado del uso público de la razón y la libertad de crítica y de comunicación, así como en su alcance político hasta llegar a afirmar que la publicidad es el atributo formal del Derecho. En efecto, Kant hará del Derecho el marco fundamental y permanente de la acción individual y del libre juego de las fuerzas sociales.

\section{3}

Como paso preliminar para describir la correcta relación que Kant establece entre derecho y moral, es necesario revisar algunas distinciones terminológicas indispensables; me refiero a tres pares de distinciones: la primera es aquella entre motivo e intención de la acción; la segunda es la distinción entre voluntad y libre arbitrio; y la tercera y última es la distinción entre ley, máxima y regla. Empecemos con el primer par.

Tomaré como sinónimos de acción los términos conducta libre o comportamiento. En primer lugar, hemos de notar que al actuar el ser humano tiene un propósito (Vorsatz) de hacer algo puesto que es un ser pensante, una conciencia reflexiva. En segundo, apreciamos que además tiene una intención (Absicht) de hacer algo, es decir, que además sabe qué interés es el que le anima, qué motivo es el que lo mueve al hacer ese algo; entenderemos por motivo de una acción un aspecto particular y específico de la intención. Así por ejemplo, alguien puede tener el propósito de tomar un cuchillo y enterrárselo a cierta persona con la intención de defenderse, o de robarla o de vengarse; con un ejemplo más, tomado de la tragedia de Sófocles, podría decirse que Edipo tiene el propósito de matar a un hombre, pero no tiene la intención de matar a su padre. Ahora bien, en un acto (Tat) no todas las consecuencias derivadas de él pueden ser imputadas a su autor puesto que actuar implica someterse también a la acción de los factores del mundo externo. En efecto: lo accidental, las fuerzas exteriores ajenas al autor de la acción, lo que no está en sus manos controlar, lo que no depende de él, puede muy bien torcer o desviar la acción (Handlung) 
llevándola a consecuencias extrañas y no previsibles ni deseadas, i.e., consecuencias no propuestas y ajenas a la intención del agente. Así por ejemplo, yo puedo tener el propósito de colocar una jardinera o una maceta de botones en flor en mi ventana con la intención de embellecer mi habitación, pero ignoro que la cantera de la fachada del edificio en la que se encuentra sostenida la base para colocar la jardinera se ha reblandecido y está floja, de modo que al colocarla el peso vence la placa de cantera y ésta cae con todo y jardinera, hiriendo mortalmente a un transeúnte. Actuar implica siempre exponerse a que lo no previsible desvíe la acción del propósito perseguido. Por ello, al autor sólo puede imputársele aquello que conscientemente se ha propuesto hacer. Si no fuera así, nadie se atrevería a actuar, estaríamos condenados a jamás actuar. Indudablemente, siempre se debe actuar con reflexión, es decir, con conciencia de las consecuencias, y por ello no se puede juzgar una acción haciendo caso omiso de sus consecuencias pues en éstas se manifiesta una parte de la naturaleza de la acción. Sin embargo, la otra parte de la naturaleza de la acción la constituye el propósito y la intención, es decir, lo que conscientemente ha querido y se ha propuesto hacer el agente, y ésta es la acción propiamente dicha, por lo cual el juicio referente a una acción ha de recaer primordialmente sobre la intención con el que ésta fue realizada y sobre la máxima que la anima.

Repasemos ahora brevemente la distinción fundamental entre der Wille y die Willkür. ${ }^{68}$ Kant utiliza el sustantivo masculino der Willie, que en castellano traduciré como la voluntad, para referirse a la razón práctica en tanto facultad que juzga cómo debe ser nuestra conducta libre, nuestra acción. Así, entiende por voluntad la capacidad de dirigir la acción gracias a la representación de la ley, la facultad de obrar conforme a leyes concebidas por cuenta propia. Por ello la razón práctica es simplemente la facultad volitiva. ${ }^{69}$ Ahora bien, la libertad

${ }^{68}$ Así por ejemplo, entre los contemporáneos de Kant, Reinhold pasó inadvertida esta importante distinción llegando por ello a la errónea idea de que no somos responsables de nuestros actos inmorales o malignos ya que al identificar plenamente voluntad con razón práctica no halló lugar para que la libre elección intervenga en una decisión moral.

${ }^{69}$ Cfr., Fundamentación de la Metafísica de las Costumbres, 412. 
pertenecerá a esta voluntad sólo en la medida en que se dé a sí misma la ley, esto es, en la medida en que sea autónoma. Por otro lado, Kant utiliza el sustantivo femenino die Willkür para referirse a la facultad superior de desear o apetecer o facultad de querer; la traducción exacta de este término es el albedrío (o el arbitrio) aunque lamentablemente a menudo se traduce lisa y llanamente como 'voluntad'. Die Wilkür es el nombre que damos a la capacidad de escoger entre alternativas; facultad de elección libre y espontánea, es ese aspecto de la facultad volitiva que implica la no dominación en la decisión libre e irrestricta. Así lo señala Kant al asentar que:

La libertad del albedrío (Willkür) es de un carácter enteramente único pues puede ser determinada a una acción por algún móvil sólo cuando el hombre ha admitido (o acogido) dicho móvil en su máxima (constituyéndolo como regla general según la cual él quiere comportarse); sólo así un móvil, sea éste el que fuere, puede coexistir con la espontaneidad absoluta del albedrío (con la libertad). ${ }^{70}$

Por ello, el albedrío (Wilkür) no es por sí bueno o malo, es más bien la capacidad por la que podemos escoger libremente máximas buenas o máximas malas. Así pues, podríamos decir que el albedrío es libre tanto en el caso que ponga como causa determinante de su obrar la forma legisladora universal de la ley moral como en el caso de que haya puesto como causa determinante los impulsos sensibles. En el primer caso el albedrío es libre y autónomo; en el segundo caso es libre pero heterónomo, pues ha escogido regirse por leyes ajenas a su voluntad. La legislación se produce espontáneamente por la razón, pero la autonomía es algo que cada ser humano debe realizar como tarea. Por eso el carácter moral o inteligible se forja y se templa de modo voluntario, entendiendo por ello libres decisiones de nuestra voluntad, de modo tal que dicho carácter signará y marcará nuestras elecciones morales específicas de vida.

${ }^{70}$ Cfr., Religión dentro de los límites de la mera razón, 23. 
Por otra parte, en la Metafísica de las costumbres, afirma Kant:

Las leyes proceden de la voluntad (der Willie); las máximas proceden del albedrío (die Willkür). Éste último es en el hombre un albedrío libre; la voluntad, que no se refiere sino a la ley, no se puede calificar de libre o no libre, pues no se refiere a las acciones, sino directamente a la legislación concerniente a las máximas de las acciones (por tanto la razón práctica misma), de ahí que sea también absolutamente necesaria y no susceptible de coerción alguna. Por lo tanto, sólo el albedrío puede ser llamado libre. $^{71}$

Así pues, la voluntad (Wille) no toma decisiones, ni adopta máximas, ni actúa; más bien realiza las funciones legislativas de la facultad volitiva y es el aspecto puramente racional de dicha facultad. En contraste, el albedrío (die Willkür) realiza la función ejecutiva de esta misma facultad volitiva unificada. ${ }^{72}$ La voluntad (der Wille) es la fuente de la que procede un móvil (la ley) que permanentemente se ofrece al albedrío para que éste lo adopte o lo asuma en la máxima que elige. Así, la voluntad puede determinar al albedrío, y la elección interviene al tomarse una determinación moral. Kant no establece una identidad estricta entre voluntad y razón práctica (de modo tal que éstas fuesen convertibles la una con la otra); está lejos de sostener que voluntad y razón práctica se identifiquen pues, de ser así, nadie podría cometer libremente un acto inmoral y se estaría sosteniendo la absurda tesis de que no somos responsables de nuestros actos inmorales pues sólo seríamos libres (y por ende responsables) al realizar acciones autónomas.

Detengámonos ahora en la importante distinción que Kant traza entre principios objetivos o leyes y principios subjetivos o máxima

${ }^{71}$ Cfr., Metafísica de las Costumbres, 226.

${ }^{72}$ No podemos detenernos aquí para exponer con todo detalle esta importante distinción entre der Wille y die Wilkür. Para profundizar en ella remitimos al lector a los siguientes trabajos: H. Allison, Kant's theory of freedom, p. 126-36; J. Silber, Ethical significance of Kant's religión, en la traducción inglesa de T. M. Grene y H. Hudson de Religion within the limits of reason alone, 1960, Harper \& Row, New York, especialmente p. xciv-cvi; y, Yovel, "Kant's practical reason as will", en Review of Metaphysics, 52/3, 1998, p. 267-94. 
y digamos además una breve palabra sobre las reglas. Kant usa el término genérico de 'principio práctico' para referirse a toda clase de proposiciones que contienen una determinación de la voluntad. Voluntad es la facultad de un ser racional de actuar de acuerdo a su representación o concepción de una ley. Gracias a un acto de su voluntad tal ser racional proyecta una intención. Tanto dicha intención como la ley en términos de la cual actúa la voluntad, son principios prácticos. Ahora bien, estos principios prácticos pueden ser de dos tipos: (1) subjetivos, en cuyo caso el principio de la voluntad es considerado por el sujeto como válido únicamente para él; y, (2) objetivos, en cuyo caso el principio es considerado como válido para todos los sujetos. Los principios subjetivos son designados por Kant con el nombre de máximas, en tanto que los principios objetivos son denominados como leyes prácticas.

Las máximas contienen la regla práctica que la razón determina en conformidad con las condiciones del sujeto (frecuentemente las inclinaciones del mismo) y es, de ese modo, el principio según el cual obra el sujeto. Por otra parte, la ley es el principio objetivo válido para todo ser racional, principio según el cual debe obrar, es decir, un 'imperativo'. Así pues, la capacidad de actuar sobre la base de principios prácticos es el rasgo característico del obrar racional.

Ya desde la primera Crítica Kant consideró la capacidad de obrar sobre la base de imperativos, en general, como la característica que define al obrar libre. Ahora bien, llevar a cabo un razonamiento práctico significa deliberar sobre qué ha de hacerse, tanto en sentido moral como pragmático. Esta deliberación requiere, como veremos a continuación, de la espontaneidad de la razón ya que implica el establecimiento de fines y reglas que no se basan únicamente en lo que de hecho se desea en un momento dado, sino que reflejan más bien lo que uno elegiría si fuera cabalmente racional. En otras palabras, un ser racional dotado de voluntad supone la superación del mundo meramente subjetivo de lo agradable como motivación última del obrar; tal ser racional no se rige por leyes dictadas por la naturaleza sino por leyes concebidas por cuenta propia. Así, razón práctica significa la capacidad de elegir la propia acción independientemente de las 
sensaciones de agrado y desagrado, de los impulsos e inclinaciones, de las necesidades y pasiones sensibles. Los impulsos, inclinaciones y necesidades tienen en los seres naturales el significado de pautas que rigen la conducta necesariamente. Por eso los seres naturales siguen sus propios impulsos e inclinaciones, mas no una voluntad propia, sino la 'voluntad de la naturaleza'. Sólo la capacidad de obrar según leyes auto propuestas permite hablar de verdadera voluntad. Razón práctica o voluntad es la capacidad de derivar acciones a partir de leyes y tanto el desear, como el deliberar y el elegir constituyen, conjuntamente, el ejercicio de dicha capacidad. Esto no significa que la voluntad deba destruir los impulsos naturales, significa más bien que es capaz de distanciarse de ellos y suspenderlos como motivación última y determinante del obrar.

Va a permitirme el lector que insista un poco más en esta capacidad de elegir la propia acción. En tanto primera persona, no podemos concebirnos como el estallido y la dispersión de innumerables elementos empíricos desunidos y discordantes: inclinaciones, deseos, sentimientos, afecciones, impulsos, emociones, gustos, recuerdos, imaginaciones, etc. Muchas veces este sinnúmero de elementos son contrapuestos e incompatibles y buscamos que "no por complacer a una inclinación releguemos todas las restantes dejándolas en la sombra, sino que cuidamos de que aquélla pueda coexistir con la suma de todas las inclinaciones". ${ }^{73}$ Necesitamos concebirnos a nosotros mismos como agentes unificados puesto que es imprescindible resolver el conflicto entre los diversos motivos que llevan a la acción, so pena de vernos condenados a la inmovilidad, no sólo física. Frente a esto no tenemos alternativa ya que en tanto primeras personas no podemos ni siquiera imaginarnos sin capacidad de actuar. Como bien lo apunta Arendt: "el hombre es en la medida en que es un ser actuante". ${ }^{74}$ En tanto primeras personas no podemos evitar no actuar, no elegir, no responder de noso-

${ }^{73} \mathrm{Cfr}$., Antropología desde un punto de vista pragmático, § 81, 266.

${ }^{74}$ Cfr., Hannah Arendt, "What is freedom?", en Between Past and Future, 1968, New York, Penguin Books, p. 460; de esta obra existe traducción castellana en Ediciones Península, Barcelona, 2003; véase p. 267 de esa edición. 
tros, no tomarnos bajo nuestro cargo. Por otra parte, debemos señalar que hay una unidad implícita en el punto de vista desde el cual se delibera y decide la acción, unidad que nos hace concebirnos como agentes unificados. Ahora bien, concebirnos como agentes unificados significa concebirnos, además, como agentes espontáneos, es decir, como el centro del cual emerge la acción, como la fuente de nuestros pensamientos y el origen de nuestras acciones, como una unidad de conciencia capaz de coordinar, organizar e integrar actividades conscientes que manifiestan nuestra voluntad y construyen nuestra identidad personal. Este rasgo de espontaneidad y construcción de nuestra identidad personal nos manifiesta que la persona está 'proyectada' hacia el futuro, pues se propone metas y fines, se traza planes y proyectos, se fija objetivos y actúa con base en ello; la persona no se agota en su aquí y ahora, sino que nuestra identidad radica en el carácter espontáneo de nuestra condición de agentes activos o prácticos y tanto el desear, como el deliberar y el elegir constituyen, conjuntamente, el ejercicio de dicha actividad. Así pues, la conexión necesaria entre la acción del agente y la unidad de éste tiene una base enteramente práctica y no se requiere apelar a fundamentos de otra índole. Gracias a dicha base práctica podemos responder a las preguntas '¿quién soy yo?’ y ‘qué debo hacer con mi vida?' sin remitirnos al acatamiento de un objeto o un bien impuesto desde fuera a la voluntad. Gracias a dicha base podemos dar cuenta y razón de nuestra arraigada convicción de que, como primeras personas, tenemos el poder de decidir qué hacemos o dejamos de hacer con nuestra vida. Gracias a dicha base podemos fundamentar y apoyar la tesis según la cual el sujeto es la fuente de la normatividad.

Regresemos al tema que nos ocupa. Las máximas son, como hemos dicho, principios subjetivos en el sentido de que el sujeto las adopta libremente, i.e., se las propone como propias, las hace suyas como productos de la elección de su libre arbitrio. En efecto, tal como Kant lo dice, ${ }^{75}$ las máximas son 'reglas auto impuestas', de modo que no se

75 Véase la línea 25 de la Fundamentación de la metafísica de las costumbres, Ak. Ausg., IV, 438. 
trata simplemente de tener una máxima sino más bien de hacer uno su propia máxima como producto de la razón práctica. ${ }^{76}$ Esto no significa que siempre debamos formularnos explícitamente nuestras máximas antes de realizar cualquier acción ni que debamos tener total certeza respecto de la motivación de nuestras máximas; significa simplemente que no podemos actuar según un principio sin tener conciencia de tal principio.

Así pues, 'máxima' es un principio práctico o una regla de acción auto impuesta. Ahora bien, debemos distinguir ${ }^{77}$ entre meros preceptos (Vorsätze) o reglas específicas e inflexibles y máximas propiamente dichas y reservar este último término para las reglas o principios prácticos autoimpuestos más generales, de modo que podríamos hablar de varios grados de generalidad o de un orden 'jerárquico' en las máximas. ${ }^{78}$ De este modo, las máximas serían las más básicas y generales 'reglas de vida' (Lebensregeln) que contienen bajo sí diversas reglas prácticas específicas y que funcionan como principios directivos de orientación global dados a la propia existencia; las máximas serían expresión de las actitudes fundamentales que confieren rumbo, orientación y sentido a las diversas intenciones y acciones concretas de la vida de los individuos; serían esos patrones o modelos globales de acción que nos permiten identificar y juzgar el carácter de una persona, que informan las acciones concretas y específicas de su biografía y que hacen que la biografía de un individuo no sea una rapsodia inconexa de acciones.

Dejando por ahora a un lado los célebres ejemplos que Kant propone en la Fundamentación para ilustrar lo que entiende por máxima, citaré lo que considero que son ejemplos adicionales de máximas que

${ }^{76}$ En efecto, Kant señala que las máximas surgen de las inclinaciones y apetitos por la colaboración de la razón; véase línea 9 de de la Fundamentación de la metafísica de las costumbres, Ak. Ausg., IV, 427.

${ }^{77}$ Véase Otfried Höffe, "Kants kategorischer Imperativ als Kriterium des Sittlichen" en Ethik und Politik, Suhrkamp, 1979, p. 84-119, especialmente p. 87-96. Véase también Rüdiger Bittner, "Maximen" en Akten des 4 Internationalen Kant Kongresses, Mainz, 6-10 April 1974, G. Funke y J. Kopper (eds.), de Gruyter, Berlin, 1974, p. 485-9.

${ }^{78}$ Véase Henry E. Allison, Kant's theory of freedom, p. 85-94, especialmente p. 93-4. 
el propio Kant nos ofrece en el primer apéndice de su ensayo Hacia la paz perpetua ${ }^{79}$ que estamos revisando. Kant señala que se trata de máximas sofísticas, máximas según las cuales actúa el falso político, es decir, el político que sostiene que hay un divorcio irremediable entre política y moralidad:

(1) Fac et excusa, que podríamos traducir como primero actúa y después busca una justificación; es decir, aprovecha la ocasión favorable para apoderarte arbitrariamente de alguna posesión o algún bien y después busca justificarte, saca partido de que tu misma audacia conferirá una cierta apariencia de convicción interior a la legitimidad del acto y eso será tu mejor abogado.

(2) Sifecisti, nega, que podríamos traducir como si hiciste algo, niégalo; es decir, niega que lo que tú mismo has cometido sea culpa tuya; afirma, en cambio, que la culpa está en los otros, en su desobediencia o en su agresiva naturaleza a la cual tienes que anticiparte.

(3) Divide et impera, que podríamos traducir como divide y vencerás; es decir, siembra la intriga, la discordia y la envidia entre tus adversarios enemistándolos entre sí, pues es el medio más rentable y eficaz para someterlos y dominarlos.

Ahora bien, debemos destacar que las diversas reglas prácticas específicas contenidas en las máximas pueden cambiar a tenor de la situación y de las posibilidades de cada agente, aunque procedan de las mismas máximas. En efecto, Kant señala ${ }^{80}$ que en contraste con la determinación general que se expresa en los principios, las reglas específicas están relacionadas con el carácter contingente y empírico de la acción en situaciones concretas e insiste en el relevante papel de lo circunstancial en estas reglas. Así, las reglas se distinguen de los principios fundamentales que expresan una auténtica norma de vida (máximas) y de los principios fundamentales que son universalmente válidos (leyes). Kant hace esta distinción para subrayar que las reglas suponen condiciones empíricas y puesto que los principios pueden ser,

${ }^{79}$ Cfr., Hacia la paz perpetua, final del apéndice I, Ak. Ausg., VIII, 374.

${ }^{80}$ En la Observación del $\S 1$ de la Crítica de la razón práctica. 
o bien leyes, o bien máximas, las reglas podrán referirse tanto a las máximas como a las leyes. ${ }^{81}$ Las reglas expresan lo que, en promedio, se enmarca dentro de un principio general, pero no valen necesariamente y sin excepción. Requieren de un sano sentido común y buen criterio para su sabia aplicación, y no pueden ser aplicadas mecánicamente recurriendo a una norma general. ${ }^{82}$ Podríamos resumir este último punto diciendo que los juicios morales no son juicios determinantes sino que pertenecen a otra clase de los juicios, a saber, los juicios reflexivos o reflexionantes y son, más específicamente, juicios prácticos. ${ }^{83}$ Kant no pretende afirmar que las reglas estén contenidas directamente en los principios como si fuesen consecuencia lógica de ellos. Lo que dice es que las reglas están contenidas en la determinación general de la voluntad, no en el principio. De este modo, a reglas idénticas pueden corresponder principios diferentes y a diferentes reglas principios idénticos. Así, dos agentes pueden dirigirse a un mismo fin y alcanzarlo siguiendo reglas diferentes. Es importante advertir que Kant insiste en esta sutil relación entre regla y principio a fin de distinguir entre las acciones morales y aquellas que son meramente legales, distinción cuyo examen será el objetivo que perseguiremos en la siguiente sección de este trabajo. Precisamente esta sutil aunque importante relación es lo que se suele pasar por alto en algunas de las críticas más frecuentes a la ética de Kant, las que insisten en que Kant pone un énfasis excesivo a la uniformidad de las acciones morales. Kant no está afirmando la aplicabilidad universal de regla alguna. La universalidad en la que insiste no es la de una regla, sino la de un principio que admite flexibilidad en la elección de las reglas. Además, una regla es siempre un 'producto de la razón', pues sólo la razón (como facultad del pensamiento en general y no como una de las tres facultades cognitivas, donde las otras dos serían la sensibilidad y el

${ }^{81}$ Véase Fundamentación de la metafísica de las costumbres, Ak. Ausg., IV, 389.

${ }^{82}$ Esto mismo vale para las reglas del juicio teórico, véase Crítica de la razón pura, A 133, B 172.

${ }^{83}$ Véase "El juicio reflexivo en la ética kantiana", en Dianoia, anuario de filosofía, n 42, México 1996, p. 125-44. 
entendimiento) puede darnos el conocimiento de la relación entre un medio y un fin, expresada en una regla.

Así pues, está hablando a la persona individual y concreta de cada quien, ése es su interlocutor puesto que: 1) la ética de Kant es una ética de máximas y éstas son principios subjetivos, principios que el sujeto saca desde sí, que genera y en los que éste se manifiesta y revela, no principios inyectados al sujeto por alguien ajeno y externo a él; y, 2) porque el juicio moral es un juicio reflexivo, más exactamente, es uno de los dos tipos en que se subdivide el juicio reflexivo: juicios prácticos y juicios teleológicos. En contraste con el juicio determinante que parte de la ley o de lo universal y va hacia lo particular, el juicio reflexivo parte de lo singular y concreto en búsqueda de lo universal. En el caso del juicio moral, lo singular y concreto es la persona individual y concreta con sus personales principios subjetivos o máximas.

\section{4}

Revisemos ahora la relación que Kant establece entre moral y derecho. Uno de los temas más importantes de la Metafísica de las costumbres ${ }^{84}$ es el examen que Kant nos ofrece de dos grupos de deberes. El filósofo señala que toda legislación comprende dos elementos: el primero es una ley que presenta como objetivamente necesaria la acción que debe suceder convirtiendo así la acción en deber; el segundo elemento es un móvil que liga subjetivamente el arbitrio con la representación de la ley, haciendo de este modo que la ley del deber sea un móvil. En efecto, como señalábamos más arriba, cuando la razón se avoca a la acción se vuelve práctica, es decir, voluntad; de modo que la voluntad es el aspecto racional de nuestra facultad volitiva porque produce leyes; no obstante, el ser humano también actúa movido por intenciones; esto equivale a decir que en nuestra voluntad se incluye, además de las leyes, a los móviles de la acción. Así pues, por medio del primer elemento, la

${ }^{84}$ Cfr., Metafísica de las costumbres, Ak. Ausg., VI, 218-21. 
acción se presenta como deber, y por medio del segundo, la obligación de obrar se une al sujeto. Atendiendo a este segundo elemento, el de los móviles, las legislaciones pueden ser diferentes. En efecto, en este punto hay que distinguir, primeramente, la legislación que hace de una acción un deber y de dicho deber un móvil, la cual recibe el nombre de legislación ética. En segundo lugar, hay que distinguir la legislación que no incluye al móvil en la ley y, por ende, admite también otro móvil distinto de la idea misma del deber, la cual recibe el nombre de legislación jurídica. Esta es una distinción de crucial importancia. En la legislación ética las acciones suceden por deber, es decir, tienen su valor moral no en lo que vaya a ser alcanzado por medio de ellas, sino en el querer por el cual han sido decididas, en el querer que ha determinado a la voluntad, a saber, el deber como móvil. En cambio, en la legislación jurídica el móvil no juega papel alguno. Lo que cuenta es que, considerada 'externamente' por un observador, la acción no sea contraria al deber jurídico, sin importar la intención del sujeto y lo que lo mueve en su 'interior': es indiferente que el móvil sea el temor, o la reputación, o la compasión o la búsqueda del honor o el deber. La legislación ética presupone, por un lado, una ley que señala cómo debe suceder una acción y, por otro lado, un móvil que nos vincula subjetivamente con la representación de la ley.

Digamos ahora una breve palabra respecto de la concordancia de una acción con la ley. Kant da el nombre de legalidad de una acción a la mera concordancia o conformidad de la acción con la ley sin tener en cuenta los móviles de dicha acción; en cambio, se llama moralidad de una acción a la concordancia de la acción con la ley en la que la idea del deber según la ley es el móvil de la acción.

En la primera parte de la Metafísica de las costumbres, que lleva por título "Doctrina del derecho", Kant se ocupa de los deberes denominados deberes jurídicos, en tanto que en la segunda parte de la obra, la cual lleva por título "Doctrina de la virtud", Kant trata los deberes denominados deberes morales o deberes de virtud. Ambos grupos de deberes tienen en común que descansan sobre imperativos categóricos y se distinguen por el tipo de legislación y el modo de obligación propio de cada uno de estos dos grupos. En efecto, los deberes nacidos de la 
legislación jurídica (por ejemplo, el deber de respetar un contrato) sólo pueden ser externos puesto que esta legislación no exige que la idea de este deber (que es interior) sea por sí misma fundamento determinante del arbitrio del agente. Por ende, estos deberes son legislados externamente y podemos vernos obligados por alguien distinto a nosotros mismos a acatarlos, es decir, en este caso es posible ejercer una coacción externa.

Es importante hacer una breve digresión para destacar que si sólo existiera la legislación jurídica, resultaría imposible que la primera persona fuera una genuina fuente de la normatividad. En efecto, el único tipo de coacción que se podría dar sería la coacción externa y tendríamos que concluir que la bondad o maldad de una acción estaría definida únicamente por la posibilidad de ejercer o no ejercer coacción externa sobre el agente. Una acción sería buena mientras no se pudiera ejercer coacción sobre su ejecutor, sin importar lo que haya hecho. Malo sería lo que de hecho se castiga, y bueno sería lo que de hecho no se castiga. También me inclino a pensar que en este caso 'obedecer' no puede significar otra cosa más que acatamiento de la dominación. Regresaremos más adelante a este tópico pues nos enfrentará a problemáticas que no podrían ser resueltas si no existiera la legislación ética y no tuviéramos la posibilidad de ofrecer, en virtud de ella, fundamentos y críticas a la legislación jurídica. En efecto, antes de proseguir es necesario subrayar que al descartar la posibilidad de la primera persona como fuente de la normatividad, algunas de las más grandes dificultades que tendrá que enfrentar el realismo político es la de no poder hacer propuestas realmente innovadoras acerca de posibles cambios y mejoras en la realidad política. Quizá ese fatalismo filosófico empobrecedor sea una de las razones de más peso para rechazar las posturas del realismo político y optar por una posición normativa. En efecto, a diferencia de las concepciones normativas de la política que tienen que hacer frente a diversos argumentos que se les oponen a fin de probar la solidez de sus tesis, el realismo político parece no tener que hacer esfuerzo alguno para demostrar la pertinencia de su postura básica, a saber, que la realidad siempre acabará imponiéndose y que ésta no es otra que la del pragmatismo 
escéptico que considera que no existen obligaciones morales, que la paz es imposible y que la guerra es necesaria. Por más que el realismo político se presente como una posición progresista y de vanguardia, resulta ser una postura retrógrada y reaccionaria que lejos de promover una sociedad abierta, incluyente y plural, es el mejor caldo de cultivo para que los movimientos sociales o políticos de reivindicación de derechos humanos originarios, universales e inviolables, resulten ilusorios y quiméricos, y para que prosperen las enormemente injustas políticas de dominación, principalmente económica, de las naciones poderosas sobre las débiles. En efecto, parece que son sólo los jefes de los Estados y los poderosos los que no llegan a hartarse de la guerra ${ }^{85}$ De aquí que me parezca muy importante tratar de examinar la vinculación que Kant nos propone entre derecho y moralidad y subrayar su carácter cosmopolita.

Por otra parte, la legislación ética convierte también en deberes acciones internas, pero sin excluir las externas, afectando así a todo lo que es deber en general, de modo que los deberes jurídicos son indirectamente deberes éticos. Pero precisamente porque la legislación ética incluye en su ley el móvil interno de la acción (la idea del deber), cuya determinación no puede desembocar en una legislación externa,

94 la legislación ética no puede ser externa, aunque admita como móviles de su legislación deberes que se desprenden de una legislación externa, en tanto que deberes. Así, los deberes morales o éticos (por ejemplo, el deber de ser fiel o de cumplir una promesa) no se nos imponen externamente por un legislador exterior, su legislación es interna y el tipo de obligación que les es propio es la autoconstricción.

Podemos resumir diciendo que todos los deberes, simplemente por ser deberes, pertenecen a la ética; pero no por eso su legislación está siempre contenida en la ética. La doctrina del derecho y la doctrina de la virtud no se distinguen tanto por sus diferentes deberes como por $l a$ diferencia de legislación que liga los móviles con la ley. La legislación ética es la que no puede ser exterior (aunque los deberes puedan ser también exteriores); la legislación jurídica es la que también puede

${ }^{85}$ Cfr., Hacia la paz perpetua, Ak. Ausg., VIII, 343. 
ser exterior. Regresemos al ejemplo que hemos ofrecido: cumplir una promesa; pongamos por caso la correspondiente a un contrato, es un deber externo; pero el mandato de hacerlo únicamente porque es deber, sin tener en cuenta ningún otro móvil e incluso cuando no puede temerse coacción externa alguna, pertenece sólo a la legislación interior. En este ejemplo es claro que la obligación no pertenece a la ética como un tipo particular de deber, como un tipo particular de acciones a las que estamos obligados - puesto que es un deber exterior, tanto en la ética como en el derecho-, sino porque la legislación es interior y no puede tener un legislador exterior. Precisamente por esta misma razón los deberes de benevolencia están incluidos en la ética, aunque sean deberes exteriores, i.e., obligaciones referidas a acciones externas, pues su legislación sólo puede ser interna. Finalmente, cabe destacar que la ética tiene sus deberes peculiares (e.g., los deberes hacia uno mismo) así como deberes comunes con el derecho, aunque no en el modo de obligación ya que realizar acciones simple y llanamente porque son deberes y convertir el principio del deber en un móvil suficiente del arbitrio, venga el deber de donde viniere, es lo específico de la legislación ética. En resumen: todos los deberes son indirectamente éticos y hay muchos que son, además, directamente éticos.

La autonomía impulsa al ser humano a usar de todas las cosas como medios para su fin. Pero en este movimiento se topa con otras libertades que hacen otro tanto, de modo que la autonomía de uno choca con la autonomía de otro y se produce el conflicto entre las libertades. Este conflicto tiene un enorme alcance pues la acción externa de los hombres forma la historia humana en su totalidad. No se trata sólo de un conflicto particular y concreto, sino de la interacción de las libertades en la constitución de la historia total de la humanidad. La realización de la libertad externa del hombre sólo puede efectuarse en el seno de esta interacción entre los diferentes seres autónomos. Ahora bien, la ley que ha de regular la coexistencia de las libertades concierne sólo a la acción externa y no al móvil de esa acción; la acción externa se refiere al libre arbitrio y la ley que regula al libre arbitrio es la ley de la libertad. De esta ley proceden todos los derechos y todos los deberes del hombre. Y el primer derecho originario del hombre es "la 
libertad (independencia del arbitrio obligante de otro) en cuanto puede subsistir con la libertad de todos los otros según una ley universal". ${ }^{86}$ Así pues, todo ser humano tiene derecho a coexistir con otros según una ley universal de libertad y, en lo referente a las acciones externas, todo libre arbitrio puede entrar en relación con otros en la medida en que todos se someten a tal ley universal de libertad.

En la Metafísica de las costumbres ${ }^{87}$ Kant define Derecho a "la suma de condiciones bajo las cuales el arbitrio de uno puede ser conciliado con el arbitrio de otro según una ley universal de la libertad", de modo que, como hemos dicho, al Derecho le concierne sólo la relación externa práctica de una persona con otra en cuanto sus acciones tienen una influencia mutua. Además, en esta relación de los arbitrios, el Derecho no considera la intención que cada uno persigue en sus acciones, sino la forma de la coexistencia de éstas según una ley universal. ${ }^{88}$ Por otra parte, esta coexistencia es susceptible de coacción externa: cuando el efecto de una libertad obstaculiza el uso de las otras, excluyéndose así de la ley de todos, pone un impedimento a la libertad según leyes universales y esto es injusto; por ende, es justo oponer una coacción a lo que es injusto; es decir, es justo remover el impedimento que obstaculiza la coexistencia de todos prescrita por la ley universal. Así pues, derecho y facultad de coaccionar forman una sola cosa pues con el Derecho "está ligada una autorización de coaccionar a aquel que causa perjuicio". ${ }^{89}$ Ahora bien, esta coacción no supone ir en contra del principio de la libertad que dicta no obedecer otra ley que aquella que la razón misma nos presenta; la coacción se dirige contra la arbitrariedad, no contra la libertad. En efecto, la razón presenta la ley de coexistencia de todos bajo una ley universal que excluye el derecho de excluirse. Confirmando lo que acabamos de decir, presentamos la definición que Kant nos proporciona de libertad exterior: "es la facultad de no obedecer ninguna otra ley que a la que

\footnotetext{
${ }^{86}$ Cfr., Metafísica de las Costumbres, Ak. Ausg., VI, 237.

${ }^{87}$ Cfr., ibid., Ak. Ausg., vI, 230.

${ }^{88}$ Cfr., idem.

${ }^{89}$ Cfr., ibid., Ak. Ausg., VI, 231
} 
yo he podido dar mi asentimiento", ${ }^{90}$ y el asentimiento aquí es dado a esa ley universal que regula la coexistencia de los libres arbitrios y que excluye la excepción a dicha ley.

Recordando la definición antes citada de Derecho, podríamos recapitular diciendo que del concepto de libertad ha surgido el concepto de derecho, pues la relación recíproca de los libres arbitrios sólo puede ser concebida en la forma de derecho; la libertad externa sólo puede realizarse en la forma de derecho. Es este un punto de enorme importancia en el cual deseo insistir. En efecto, en tanto primeras personas, i.e., en tanto agentes libres y responsables, no podemos ni siquiera imaginarnos sin la capacidad de actuar. Quiero subrayar las palabras de Hannah Arendt en su famoso ensayo What is freedom?:

La acción y la política son las únicas cosas en las que no podemos ni siquiera pensar sin asumir al menos que la libertad existe: no podemos abordar un solo tema político sin tratar, implícita o explícitamente, el problema de la libertad del hombre; la libertad no es uno más entre los muchos temas políticos, como lo son la justicia, el poder o la igualdad; la libertad es en rigor la causa de que los hombres vivan juntos en una organización política; sin ella la vida política como tal no tendría sentido. La raison d'être de la política es la libertad, y el campo en el que se aplica es la acción. ${ }^{91}$

Y en otro lugar de ese mismo ensayo, la discípula de Heidegger señala: "sin un ámbito público políticamente garantizado, la libertad carece de un espacio mundano en el que pueda hacer su aparición [...] la libertad como hecho demostrable y la política coinciden y se relacionan entre sí como las dos caras de una misma moneda". ${ }^{92}$

Según ha quedado señalado, el Derecho no considera el fin que cada agente puede proponerse para sus acciones sino sólo la forma de coexistencia de los arbitrios según una ley universal; regulando de este modo la relación de los libres arbitrios, el Derecho, en primer lugar,

${ }^{90}$ Cfr., Hacia la paz perpetua, Ak. Ausg., VIII, $350 \mathrm{n}$.

${ }^{91}$ Op. cit., p. 440, correspondiente a la p. 231 de la traducción española.

${ }^{92}$ Cfr., ibid., p. 235 de la traducción española. 
garantiza la libertad de cada uno y, en segundo lugar, garantiza la igualdad de todos ante la ley; por ejemplo: cualquiera puede hacer valer frente a mí su derecho de coacción, pero no puede obligarme a alguna cosa sin que esté igualmente sometido a esa misma ley de coacción. En otras palabras: la libertad es entendida como no dominación pues la ley de coacción sólo es válida si vale universalmente.

De este modo, el Derecho expresa y manifiesta objetivamente el contenido mismo de la ética y quiere que el ideal moral se realice en la experiencia. En efecto, Kant se refiere en numerosos lugares a la moral como teoría del derecho, baste citar el ensayo Hacia la paz perpetua,,$^{93}$ en el que al menos cuatro veces encontramos dicha mención, así como la segunda sección de la obra de 1798, El conflicto de las facultades que lleva por título "Si el género humano se halla en progreso constante hacia mejor." ${ }^{94}$ En ambas obras, Kant nos presenta el Derecho como la realización histórica de la moral; sin embargo, la realización efectiva de una idea no puede ser, por definición, absolutamente adecuada con la idea. Esta inevitable inadecuación traza la diferencia entre moral y derecho y, a la vez, une en el sistema total de la moralidad en general. Así, las leyes jurídicas no sólo deben ser cumplidas, sino que además tienen que ser cumplidas. En otras palabras: a quien no las cumpla por convicción propia, por deber, por moralidad, hay que obligarlo a cumplirlas, hay que hacérselas cumplir por la fuerza; sin embargo, esta coacción tiene para Kant una fundamentación ética y el concepto de coacción es definido en función del concepto de libertad. Insistamos en esta idea central diciendo que libertad significa no dominación. En efecto, coacción es el acto que impide poner resistencia a la libertad; el Derecho y su rasgo característico de coacción son entendidos como posibilidad de unir las acciones que entran en relación con la libertad de los demás en una realización aproximada de la libertad, es decir, del ideal moral.

${ }^{93}$ Cfr., Hacia la paz perpetua, Ak. Ausg., VIII, 370, 383-386.

${ }^{94} \mathrm{Cfr}$., El conflicto de las facultades, Ak. Ausg. VII, 77-94. véase especialmente $\S 6$ de la segunda sección, Ak. Ausg. VII, 85-6. 


\section{5}

Dadas las limitaciones del presente trabajo, no podré detenerme aquí a revisar la concepción kantiana de Estado jurídico y lo que ella implica. Sólo diré que, para Kant, un Estado jurídico es aquel en el que sus participantes están libres de dominación, o en otras palabras: tienen dominio preciso y seguro de su libertad externa. Ello implica los siguientes supuestos:

1. Que exista un poder político ejercido a través de la ley y sometido a ésta.

2. Que exista un conjunto de leyes claras y reconocidas que especifiquen a qué tiene derecho cada participante, así como lo que le está permitido, lo qué le está prohibido y lo que le es exigido.

3. Que exista un modo reconocido de producir interpretaciones autorizadas de dichas leyes, cuando el significado o implicación de éstas sea controvertido. Este tercer requisito exige, a su vez, que las leyes interpretadas sean: a) completas, b) consistentes, y, c) aplicadas eficazmente.

4. Que en dicho Estado jurídico exista una separación de poderes en tres esferas: legislativo, ejecutivo y judicial.

5. Que la esfera legislativa sea soberana absoluta, es decir, que decida cómo instituir el poder ejecutivo y judicial y que su autoridad no esté limitada. De lo que acaba de decirse se sigue que la rama legislativa no puede ser ejecutiva.

Es importante destacar que Kant acepta gradaciones en estos cinco supuestos requeridos para hablar de un Estado jurídico, pues ello nos evitará caer en un falso dilema. En efecto, es posible aceptar como jurídicos Estados existentes en los cuales no se cumplen los supuestos de un modo pleno pero sí en un grado suficiente para que el dominio de la libertad externa de los participantes tienda progresivamente a ser más segura.

Por otra parte, señala que un Estado jurídico puede ser republicano si además de cumplir con la separación de poderes la soberanía 
recae en el pueblo. Este rasgo del republicanismo kantiano es de gran importancia y deberá ser examinado detalladamente. Por ahora debemos referirnos a los primeros trazos de la propuesta de Kant para lograr un orden global justo. A primera vista, parece que existen dos modelos: 1) Una liga pacífica o liga de Estados libres, y, 2) Un Estado internacional o República mundial.

Una liga de Estados soberanos resulta insuficiente para alcanzar aquello que puede verdaderamente asegurar la paz, a saber, una condición jurídica plena, es decir, el todo de una constitución civil justa. En efecto, una condición jurídica plena requiere de interpretaciones autorizadas que delimiten los poderes de los diversos Estados entre sí. La institución de una corte internacional para resolver disputas entre Estados exigiría que las autoridades nacionales reconocieran su competencia y jurisdicción. De este modo, tal corte tendría autoridad para invalidar disputas y esta autoridad anularía la soberanía nacional; por ello, la simple liga de Estados soberanos no puede alcanzar una condición jurídica plena.

Empero, para Kant era muy importante desarrollar una liga pacífica de Estados soberanos pues, si bien no es la condición jurídica plena, sería más cercana la realización de la república de la humanidad que el estado de libertad salvaje y sin ley al que se entregan hombres y naciones. Además, no se debe usar la fuerza para establecer una República mundial; los Estados deben abandonar su condición anómica pero no deben coaccionarse entre sí para hacerlo; en efecto, Kant no quiere una monarquía universal o Estado mundial no republicano pues éste sería un Estado despótico que no produciría una condición jurídica, antes bien sería un desalmado despotismo. Si Kant hubiese pensado que una República mundial o condición jurídica plena es irrealizable, no habría escrito que el estado de naturaleza de los pueblos es un estado del que se debe salir para entrar en un estado legal; de ahí que un Estado jurídico global sí sea a su juicio viable y realizable.

Aceptar gradaciones en los cinco supuestos requeridos para hablar de un Estado jurídico, nos permitiría no estar en la necesidad de escoger entre un Estado internacional o único gobierno global y una asociación libre de Estados soberanos. De ese modo, Kant mismo 
nos propone la posibilidad de un paradigma intermedio, ${ }^{95}$ que nos recuerda la imagen de los círculos concéntricos sugerida por Cicerón y los estoicos, a saber, un esquema multinivel en el que la autoridad política suprema esté verticalmente dispersa pero que también existan unidades políticas más pequeñas. En este punto podemos apreciar al gran pensador político que fue Immanuel Kant, pues fue capaz de imaginar y prever este tipo de estructura multinivel ${ }^{96}$ (como el que está emergiendo actualmente en la Unión Europea) y que, si se globaliza, puede perfectamente ser la mejor posibilidad para lograr una república de la humanidad y una paz duradera.

La ley de la libertad prescribe como deber la unión de todos en un ser común jurídico; tal unión sólo puede ser alcanzada en una sociedad en la que se dé la mayor libertad posible y, a la vez, la mayor garantía de los límites de esa libertad para la convivencia común. Dicha sociedad sólo podrá posibilitar tal realización de la libertad de todos si es regida por una Constitución civil justa que sea expresión de la voluntad pública, fuente de todo derecho y que no puede ser otra que la voluntad de todo el pueblo. ${ }^{97}$ Kant usa la expresión contrato originario para referirse a la ley fundamental que surge de esta voluntad universal y pública y califica de republicana a la constitución que de aquí se deriva. ${ }^{98}$ Dado que esta constitución ha surgido del concepto de derecho, es un deber realizarla. ${ }^{99}$ No puede ser más taxativo al decir que el único tipo de constitución del que puede nacer la paz perpetua es la constitución republicana. Esta exigencia se expresa por dos razones: en primer lugar, porque es la única forma de organización política que concuerda con el derecho innato a la libertad que tienen todos y cada

${ }^{95}$ Cfr., Metafísica de las Costumbres, Ak. Ausg., VI, 311 líneas 22-25; véase también Crítica de la Facultad de Juzgar, Ak. Ausg., V, 432 líneas 33-37 y Acerca del refrán "quizá esto pueda ser cierto...", Ak. Ausg., VIII, 312, líneas 25-29.

${ }_{96}$ Véase Thomas Pogge, Pobreza en el mundo y derechos humanos, 2005, Barcelona, Paidós, especialmente el capítulo 2.

${ }^{97} \mathrm{Cfr}$., el ensayo de 1793 Acerca del refrán "tal vez esto es cierto en teoría pero no sirve para la práctica", Ak. Ausg., VIII, 295.

${ }^{98}$ Cfr., Hacia la paz perpetua, Ak. Ausg., VIII, 350; véase también Si el género humano se halla en progreso constante hacia mejor, § 7, Ak. Ausg., VII, 88.

${ }^{99}$ Cfr., ibid., § 8, Ak. Ausg., VII, 91. 
uno de los seres humanos; y, en segundo, porque favorece y promueve el establecimiento de un orden jurídico internacional.

Para Kant el contrato originario es una idea de la razón pero que tiene realidad práctica indudable, a saber, la de obligar a todo legislador a promulgar leyes tales que hubiesen podido emanar de la voluntad unificada de todo el pueblo y a considerar a todo subordinado, en la medida en que pretende ser ciudadano, como si estuviese de acuerdo con tal voluntad. ${ }^{100}$ En efecto, es deber tener la ley por justa sólo si es posible que el pueblo concuerde con ella. Así, la razón prescribe que todos los miembros de un pueblo se unan bajo leyes jurídicas justas y de coacción en una Constitución civil que garantice la libertad de cada uno, la igualdad de todos, la co-legislación de todos y cada uno de sus miembros y, de este modo, la paz perpetua.

Ahora bien, de poco le sirve a un pueblo esta constitución civil si los pueblos vecinos no la respetan y está continuamente amenazada su libertad; la garantía de su libertad sólo puede ser salvaguardada si el contrato originario de dicho pueblo se prolonga y extiende hasta formar una alianza de pueblos en la que las distintas naciones se dan a sí mismas análogas constituciones civiles y se asegura la libertad y los derechos de cada Estado miembro. ${ }^{101}$ En efecto, la ley de la libertad ordena el deber de llegar a un "estado jurídico de Federación concertado en común por ser condición de posibilidad para el desarrollo de la libertad dentro de cada Estado. ${ }^{102}$ Así pues, las relaciones entre los diversos Estados deben estar sometidas a una Constitución cosmopolita concertada en común según la idea de un Derecho público de hombres en general. ${ }^{103}$ El Derecho encarna la posibilidad de unir la coacción recíproca universal con la libertad de todos y sólo una constitución cosmopolita puede garantizar una paz duradera para todos. Esta paz universal perdurable es la meta de todo derecho y constituye el fin y término de la doctrina del derecho en los límites de la mera razón

\footnotetext{
${ }^{100}$ Cfr., el ensayo de 1793 Acerca del refrán..., Ak. Ausg., VIII, 297.

${ }^{101}$ Cfr., Hacia la paz perpetua, Ak. Ausg., VIII, 354.

${ }^{102}$ Cfr., Acerca del refrán..., Ak. Ausg., VIII, 311.

${ }^{103}$ Cfr., ibid., Ak. Ausg., VIII, 310 y Hacia la paz perpetua, Ak. Ausg., VIII, 360
} 
pues sólo el estado de paz asegura el libre ser y obrar en común de los hombres. ${ }^{104}$

Es necesario poner de relieve la importancia de estas tesis kantianas, destacando las condiciones que harían posible esa constitución cosmopolita y su realización en estructuras políticas de multiniveles, condiciones de posibilidad que podrían resumirse en dos: la libertad comunicativa o comunicación libre de dominio y la capacidad cabal de iniciar o empezar. ${ }^{105}$

Kant se propone desarrollar una forma republicana de cosmopolitismo que permita establecer una concepción de la no dominación que lleve a la formación de una república de la humanidad cuyo fin sea hacer efectiva la realidad de la no dominación. Para el filósofo, es necesaria una república de repúblicas para frenar las tendencias de las repúblicas a ejercer imperium (imperar) sobre otras comunidades menos desarrolladas, oponiéndose así a las graves injusticias a las que las somete ese dominio y a la destrucción de la libertad común de la humanidad.

Desarrolla una concepción claramente normativa según la cual la no dominación está asegurada sólo si el poder normativo de uno no se puede cambiar arbitrariamente. Podemos decir que, gracias a esta concepción normativa, es posible que los derechos humanos universales y básicos sean considerados precisamente como esos poderes normativos suficientes para asegurar la no dominación. Concebidos republicanamente, los derechos humanos pueden ser productores del estatus más básico, es decir, de la condición de ser miembro de la comunidad humana. Por otra parte, esto nos podía permitir delinear una concepción de la democracia cuyo núcleo básico es el poder normativo para iniciar la deliberación entendida como base de la libertad común $y$ de la no dominación. En efecto, el problema político transnacional sigue siendo la dominación. A mi juicio, el cosmopolitismo republicano que Kant propone afirma la importancia no sólo de una pluralidad

${ }^{104}$ Cfr., Metafísica de las Costumbres, Ak. Ausg., VI, 355.

${ }^{105}$ Cfr., Hannah Arendt, op. cit., p. 256. 
de formas democráticas sino también la necesidad de instituciones transnacionales en favor de un federalismo transnacional.

Así, la integración política de la humanidad se convierte en un medio para evitar las grandes injusticias de la dominación. La alternativa al imperio no es la división del mundo en pueblos autónomos, sino más bien la creación de federaciones basadas en redes de reciprocidad entre los varios niveles de las instituciones republicanas, incluyendo el compromiso de refrenar el dominium del Estado y el imperium fuera de sus fronteras.

Pero es necesario subrayar que esto reclama no sólo el imperio de la ley, sino sobre todo una sociedad civil activa que convierta el poder ejecutivo en todos sus niveles en objeto de escrutinio y debate público abierto. En efecto, lo importante es que los poderes que toman las decisiones estén institucionalizados democráticamente, de modo que los agentes adquieran conciencia de la función normativa de ciudadanos y las libertades y poderes que otorga la condición de ser miembro de la comunidad humana. Los ciudadanos pueden exigir un sistema internacional de instituciones que limite las ambiciones imperialistas de sus propios países. De esto se sigue que habrán de existir algunas instituciones supranacionales si los Estados democráticos han de volverse más democráticos y han de expandir más el espacio público de la libertad común, incluso dentro de sus propias fronteras.

Así pues, la no dominación se define en términos de poderes normativos; específicamente, es la capacidad de los ciudadanos para crear y modificar sus propias obligaciones y deberes. En contraste, la dominación es la habilidad de imponer arbitrariamente obligaciones y deberes, así como cambiar arbitrariamente las condiciones normativas de las personas dominadas sin que éstas puedan apelar o poner remedio. El poder normativo de la ciudadanía es necesario precisamente como poder para moldear democráticamente el contenido de las obligaciones políticas. El poder normativo más básico de la ciudadanía es el poder positivo y creativo para interpretar, amoldar y reformar los poderes normativos que poseen los agentes políticos que tratan de imponer obligaciones y deberes a otros sin permitir que éstos interpelen. 
Entendida normativamente, la no dominación está ligada al ejercicio de la libertad comunicativa o, comunicación libre de dominio que se señaló en la segunda sección de este trabajo, y que es un poder activo que ha de ser incluido entre aquellos poderes necesarios para establecer y asegurar las relaciones sociales libres y con ello la paz.

El uso público de la libertad comunicativa hace posible el uso de normas existentes para dar contenido a las obligaciones mutuas y para crear nuevas normas por medio de una deliberación conjunta. Los poderes específicamente normativos regulan las relaciones y poderes sociales haciéndolos capaces de cambiar normas y reglas. Así, la desconcentración del poder en múltiples niveles es un importante medio para llevar a cabo una no dominación fuerte y amplia. Necesitamos construir estructuras institucionales de cooperación que busquen desconcentrar el poder y promover la deliberación en los diversos niveles de las comunidades políticas. Igualmente, necesitamos promover la separación de poderes transnacionales centralizados, redistribuyéndolos entre los ciudadanos y abriendo su deliberación. Necesitamos construir los mecanismos para una realización efectiva de los derechos humanos que vaya más allá de las instituciones de los Estados-nación particulares. Hemos de buscar estructuras diferenciadas y poliárquicas superpuestas que permitan una realización más efectiva de estos derechos y den cauce a sus respectivos reclamos contra la dominación. Este poder normativo fundamental es el poder básico que debe hacerse extensivo a todos y cada uno de los seres humanos y que podemos enunciarlo usando las célebres palabras que utilizó Hannah Arendt como el derecho a tener derechos. ${ }^{106}$ Mientras no ocurra que los poderes normativos puedan hacerse extensivos a todo

${ }^{106}$ Esta célebre frase de Arendt se encuentra en la versión en inglés de The Origins of Totalitarianism, en el capítulo nueve titulado "The Decline of the Nation-State and the End of the Rights of Man”, p. 296, Harcourt Brace Jovanovich, Publisher, San Diego, Londres y Nueva York. Año original 1948-51; la página que estoy citando corresponde a la edición de 1975. Véase también el excelente libro de James Bohman, Democracy across Borders: from Dêmos to Dêmoi, 2007, MIT Press. Del mismo autor véase además “Transnational Democracy”, en Cécile Laborde and J. Maynor, eds., Republicanism and Political Theory, 2008, London, Basil Blackwell, p. 190-216. 
ser humano, el poder que se ejerce en alguna institución particular es, en última instancia, arbitrario y contrario a la promoción de la paz. Así como teníamos la obligación de salir del estado de naturaleza y crear una civilización, así también tenemos la obligación hacia la humanidad de crear una civilización cosmopolita. Ese compromiso a favor de la paz y los derechos humanos exige que las instituciones que crean y promueven la condición cívica tengan un horizonte global. Este derecho a tener derechos denota una cualidad moral, cualidad en virtud de la cual nos podemos identificar como individuos humanos y que forma el núcleo básico para la atribución de derechos. De este modo, la humanidad es entendida en términos de una propiedad moral y puede quedar definida como una comunidad politica absolutamente incluyente. Cuando Kant nos pide que respetemos la humanidad del otro, está señalando las exigencias morales nacidas de que las personas tienen sus propios fines intrínsecos y son las fuentes auto originantes de lo que en justicia les es debido, puesto que son agentes poseedores de una razón moralmente práctica. La dignidad es el objeto específico de la humanitas y es un estatuto moral que implica una autoridad que se pide para sí mismo al reconocerla recíproca y libremente en los otros, autoridad que está ligada a la capacidad racional de ser la fuente originante de la normatividad y de los valores.

Esta capacidad normativa de fijar fines es un estatus normativo que es efectivo en relación con otros individuos que también son miembros de esa comunidad completamente inclusiva de interacción, de modo que es sólo en relación a la humanidad entendida en este sentido que tienen valor intrínseco la democracia y los derechos políticos. Ahora bien, es preciso destacar que este valor intrínseco está presente no sólo en el caso de quienes son sujetos de derechos humanos que viven en una comunidad política plenamente realizada, sino también en el caso de personas que no tienen derechos civiles y que, al carecer de todos esos estatus y poderes, su condición humana ha sido violada. En estos casos se trata de la pérdida arbitraria de la humanidad, del no reconocimiento de la capacidad de tener un estatus en cuanto tal, o en palabras de Arendt, de no pertenecer a ninguna comunidad. Aquí se ha perdido el estatus humano, la condición humana, es decir, 
la posición que es necesaria para exigir el respeto de los demás. Esto significa que debemos pensar la no dominación como el derecho a tener la condición de miembro de la comunidad humana; es el estatus normativo más fundamental, el poder normativo más básico, el derecho a tener acceso a la condición, los estatutos y los poderes que le dan seguridad a nuestra libertad y hacen posible la paz. Es la forma más básica y elemental de no dominación sin la cual no es posible alcanzar la paz. No podemos reclamar este derecho sin instituciones políticas que permitan que una comunidad sea interpelada por aquellos cuyos estatus básicos han sido violados. Son necesarias instituciones transnacionales para asegurar ésta, la forma más básica y elemental de no dominación, porque el único medio efectivo de hacer real la paz y la no dominación es la libertad común.

Por supuesto, se podría objetar que la falta de un gobierno mundial impide que la humanidad pueda ser tomada como una comunidad política, una entidad colectiva; sin embargo, la humanidad es una propiedad moral consistente en una compleja gama de capacidades que tenemos en común unos con otros en la medida en la que somos libres. Por lo tanto, el régimen de derechos humanos y sus instituciones constituye la humanidad en sentido político. Esto significa que, a falta de autoridad civil y leyes, a las personas que presuntamente no tienen derechos ni están bajo el resguardo de ningún Estado, lo único que les queda hacer, según la memorable frase de Locke, sería "alzar sus manos clamando al cielo". ${ }^{107}$ Así pues, tener derecho a ser miembro de la comunidad humana es condición sin la cual no es posible alcanzar la paz y viene junto con el poder normativo de tener derechos. Es, precisamente, lo que significa la frase elíptica de Arendt el derecho a tener derechos, i.e., el derecho a tener un estatus que haga posible el ejercicio de todos los poderes normativos que brotan del agente como fuente y origen. Este derecho a ser miembro de la humanidad no es asunto de soberanía nacional ni de elección de alguna comunidad política que garantice tal condición. Es el estatus necesario para compartir una libertad común con todos aquellos con quienes interactuamos. La

${ }^{107}$ Locke, Essay on Civil Government, segunda parte. 
condición de ser miembro de una comunidad política absolutamente incluyente puede convertir en estatus y poderes el reclamo a tener derechos. Las comunidades políticas tienen que ejercer los poderes normativos que aseguren la no dominación en común con otras comunidades de la misma índole y, por lo tanto, crear junto con ellas una condición civil común partiendo del compromiso con el ideal de la paz y de la libertad como no dominación.

Ahora bien, con el fin de tener una legitimidad democrática plena, los Estados-nación han de hacer extensivo un mínimo de ciertos estatus y poderes a todas las personas, generándose así en las democracias obligaciones especiales para establecer la república de la humanidad. El mínimo poder necesario para llegar al umbral de la no dominación democrática requiere de más autoridad legítima. Es decir, requiere del contraste republicano entre ciudadanos y personas sin derechos, personas que carecen de la libertad común. Los ciudadanos tienen la facultad compartida de iniciar el proceso de deliberación, de tener funcionarios o gobernantes que respondan a sus intereses y de fijar los puntos de una agenda. Esta iniciativa es la suprema capacidad humana y políticamente es idéntica a la libertad humana. Según hemos visto en la segunda sección de este trabajo, esta capacidad cabal de empezar o iniciar conlleva en sí los poderes normativos necesarios para deliberar y para llamar a cuentas a aquellos que deliberan. Así pues, el derecho a ser miembro es el primer bien social y es la base del reconocimiento. La condición de miembro se define en términos de las libertades básicas para las cuales ella habilita y que se manifiestan en la deliberación común.

En efecto, uno puede influir en los términos de la cooperación con otros y no simplemente ser gobernado por ellos. Así pues, la concepción de la obligación a rendir cuentas presupone los estatus y poderes normativos que el ciudadano ha de tener a fin de evitar la dominación. Los ciudadanos estarán libres de dominación sólo si son capaces efectivamente de poner en cuestión cualquier clase de interferencia que no corresponda a sus intereses relevantes. Con el fin de que el cuestionamiento sea efectivo, debe ocurrir dentro de las instituciones deliberativas; así, el poder intrínseco de los ciudadanos para cuestionar 
decisiones depende del poder aún más básico de participar efectivamente en la deliberación; el cuestionamiento se basa en el poder aún más fundamental de iniciar una deliberación. Esta capacidad deliberativa es esencialmente constitutiva de la no dominación y no meramente instrumental. De este modo, el desplazamiento de nuestro cuestionamiento inicial hacia la deliberación manifiesta que es necesario que se piense la idea de no dominación en términos de poderes normativos y no simplemente como el estar libre de interferencias arbitrarias. Requiere que se reconozca la capacidad de pensar por cuenta propia, en la que tanto énfasis ha hecho el filósofo de Königsberg.

La democracia está justificada intrínsecamente sólo en la medida en que es constitutiva de los derechos políticos y de la no dominación, y no meramente porque sea el mejor medio para alcanzar tales metas. Iniciar la deliberación es el resorte que dispara el poder político de un modo distinto del mero cuestionamiento y desaprobación post facto. Esta interacción dinámica y creativa entre libertad de iniciativa y rendición democrática de cuentas es lo que hace posible que los ciudadanos hagan sus democracias más justas y más obligadas a rendir cuentas. Ahora bien, el umbral democrático de la libertad como capacidad de iniciar puede verse bajo dos formas: la primera es la capacidad de los ciudadanos para enmendar el cuadro normativo básico, es decir, para cambiar los modos en los que se asignan derechos y obligaciones; la segunda es la capacidad de los ciudadanos para fijar un asunto en una agenda abierta e iniciar así deliberaciones públicas conjuntas. Por otra parte, una comunidad política completamente inclusiva requiere de una deliberación completamente abierta y libre de dominio. Sin la apertura de la deliberación a los otros, sigue siendo posible que una comunidad política sea dominadora de otras y ejerza sus poderes normativos de modo arbitrario. La humanidad emerge en las luchas por el estatus y condición de miembro y su papel es fungir como destinatario de los reclamos de justicia a los que puede dar respuesta una comunidad democrática cada vez más amplia y vigorosa. No podemos ignorar los reclamos de los derechos humanos de los inmigrantes, trabajadores huéspedes y minorías culturales sin convertirnos en domi- 
nadores y sin minar las condiciones necesarias para la democracia y la libertad común.

Las comunidades democráticas que respetan y honran el mínimo democrático para todos, no sólo actúan por el beneficio de la humanidad, sino que también constituyen la comunidad humana entendida como la base de la libertad común que compartimos con todos. Así, los derechos humanos universales nos conducen a una república de la humanidad en la cual las libertades básicas están justificadas negativa y positivamente. Negativamente, como las condiciones necesarias para evitar los grandes daños de la dominación y la exclusión. Positivamente, como las condiciones necesarias para vivir una vida humana digna de ser vivida. En ambos casos, ser miembro de la humanidad, entendida como el derecho a tener derechos, es, por lo tanto, la más básica de las libertades humanas. Ese es justamente el sentido que guarda la Declaración Universal de los Derechos Humanos al afirmar: "Toda persona tiene derecho a que se establezca un orden social e internacional en el que los derechos y obligaciones proclamados en esta Declaración se hagan plenamente efectivos."

Así pues, el logro de la paz perpetua incluye el reconocimiento de que tener derechos humanos viene junto con el poder o derecho normativo a tener derechos y éste no estriba en otra cosa que en el derecho de reclamar justicia a la humanidad o a la comunidad política humana de cuyo reconocimiento dependen estos derechos. Los estatus normativos de las personas, en cuanto miembros de la comunidad política humana, también traen consigo la capacidad constitutiva de crear instituciones en las que la democracia pueda desarrollarse en el sistema internacional. En esta responsabilidad de crear un sistema político global se tendrían que distribuir derechos y responsabilidades en muchos niveles diferentes de instituciones legales que se refuercen mutuamente. Este derecho fundamental a tener un orden institucional que haga efectivos los derechos, en tanto poderes normativos, requiere que deliberemos acerca de la comprensión jurídica de los derechos con el fin de que las diversas instituciones que protegen los derechos humanos no impongan obligaciones arbitrarias y que esa deliberación sea ejercida en aquellas mismas instituciones políticas internacionales que 
establecen el derecho a tener derechos. La paz y la libertad entendida como no dominación pueden ser realizadas en una comunidad política de pluriniveles, altamente diferenciada, descentralizada y con la libertad común como cometido. La humanidad puede ser efectiva en una estructura deliberativa y poliárquica, interconectada y traslapada, que busque desconcentrar sus poderes en numerosos foros institucionales diferentes, a fin de volver realidad efectiva la libertad común. Una comunidad política tal haría posible la paz y la no dominación no sólo en los Estados-nación individuales, sino también en una estructura institucional supranacional que incluya al menos algunas instituciones globales cuyo propósito sea promover la deliberación que dé lugar a la inclusión del otro y a la realización más amplia posible de la libertad común. Las interconexiones entre democracias a nivel local, nacional $\mathrm{y}$ transnacional, pueden ayudar a crear y fortificar las condiciones para un proyecto que promueva la paz y la no dominación. Las consecuencias de hacer extensivos los derechos sólo a las comunidades políticas territorial y demográficamente delimitadas son la autoderrota de la paz y la democracia y hace que estas comunidades se tornen dominadoras. Kant ha argumentado que un republicanismo cosmopolita vincula el compromiso de la paz y la no dominación con el ideal de una república de la humanidad, que estaría constituida por muchas comunidades políticas interrelacionadas e interactivas. En ella los principios republicanos básicos requieren de instituciones transnacionales, incluso globales, dadas las circunstancias modernas complejas y globalizadas. En efecto, la condición de miembro en una sola comunidad política no es suficiente para garantizar la no dominación; es necesario, además, que los poderes normativos estén distribuidos transversalmente en los diferentes niveles institucionales y las comunidades, incluyendo las instituciones transnacionales y la comunidad política de la humanidad. El paradigma de la democracia es aquel en el que es efectivo el mínimo democrático en la libertad común de la humanidad. Los imperativos morales pueden ser pensados también para conducir más directamente a la humanidad como una comunidad, más legal que política, en la cual los derechos humanos sean considerados como estatus jurídicos que se hacen efectivos institucionalmente. Esto requiere que los poderes 
normativos de la ciudadanía sean transnacionales y que den lugar a una constitución política igualmente transnacional. El régimen de los derechos humanos con objetivos republicanos inaugura un horizonte para la comunidad política transnacional en la medida en que su implementación sea elevada a materia de deliberación democrática. Ese movimiento global para promover los derechos civiles sería útil no sólo para iniciar un proceso de formación de una comunidad política humana sino también para poner a prueba las diversas posibilidades para implementar e interpretar los derechos humanos a nivel local y global y para dar base firme a nuestra esperanza de alcanzar la paz.

A lo largo de este trabajo hemos dicho que el ejercicio público de la razón y el principio de publicidad nos señalan que a la base de esta legislación cosmopolita y formando parte de ella se encuentra la pública exposición de los propios pensamientos y que esto forma parte del derecho originario de la razón humana común de la que todos participan. También hemos insistido en que, gracias a ello, el ser humano tiene la facultad compartida de iniciar el proceso de deliberación, y que esta iniciativa es la suprema capacidad humana y políticamente es idéntica a la libertad. También hemos tratado de presentar las condiciones que harían posible una estructura política

112 de la que surgiera aquello que Kant soñó y buscó con tanta esperanza: una paz duradera para la humanidad. Digo esperanza porque no fue la suya una simple esperara inactiva, sino algo por lo que trabajó intensa e incansablemente con lo mejor de su capacidad argumentativa. Y digo soñar porque fe usando precisamente esa palabra como Kant se refirió a la paz, y a él mismo, en los primeros renglones con los que da inicio el ensayo que acabamos de revisar. ¡Qué cierta resulta la respuesta de Aristóteles que sirve de epígrafe en este trabajo: ${ }^{108}$ ¡la esperanza es el sueño del hombre despierto!

${ }^{108}$ Otro lugar en el que Kant se refiere a la estrecha semejanza que guardan la esperanza y el soñar es Crítica de la facultad de Juzgar, Ak. Ausg., v, 334. 